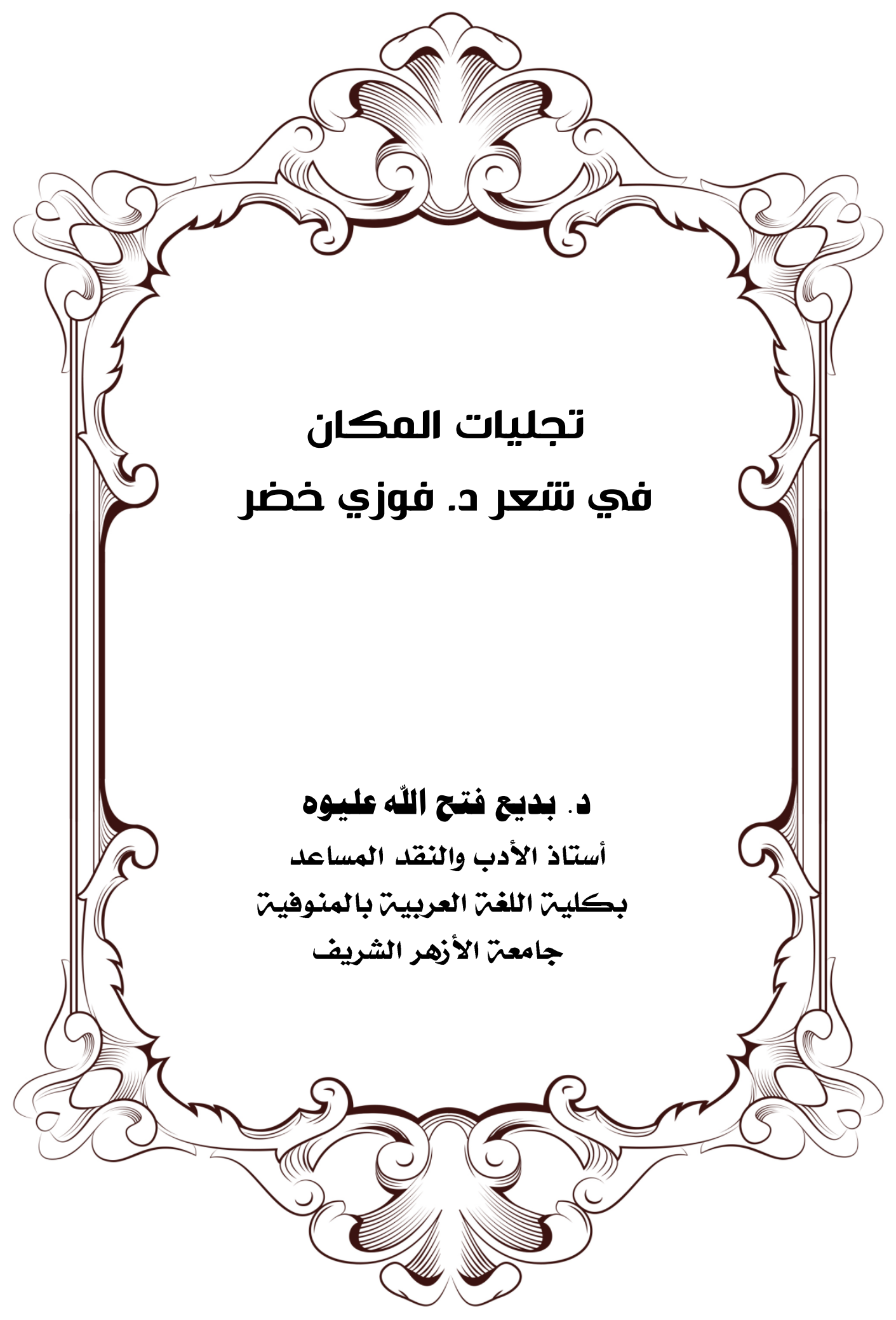



حوليت كليت اللغت العربيت بإيتاي البارود (العدد الثالث والثلاثون)

$$
\text { تجليات المكان في شعر د. فوزي خضر }
$$

بلديع فتح اللّه عليوه

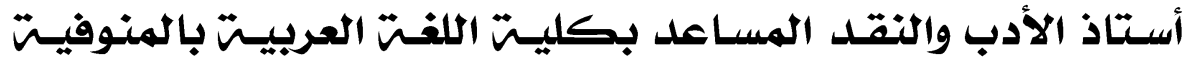

$$
\text { جامعت الأزهر - مصر. }
$$

البريد الإلكتروني: Badieeliwa.lan@azhar.edu.eg ملخص البحث: يدرس هذا البحث تجليات المكان في شعر فوزي خضر من خلال ديوانه المعنون (تدور بي دوائري) والصادر عن الهيئة المصرية العامة

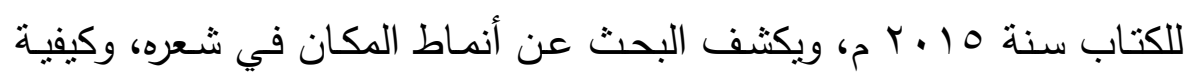
تفاعله معهه، ورؤيته له وما استخدمه من عناصر الصورة الفنية المكانية كاشفاً بذللك عن مساحة مهمة من إبداع الثاعر . الكلمـات المفتاحيـة: أدب، شـعر، المكان، فوزي خضـر، تجليـات، تدور بـي دوائري، بديع عليوه. 
حوليتّكليت اللغت العربيت بإيتاي البارود (العدد الثالث والثلاثون)

\section{The manifestations of the place in the poetry of Dr. Fawzi Khadr}

Badie fatah allah eliwa

Assistant Professor of Literature and Criticism at the Faculty of Arabic Language in Al-Azhar University - Egypt Email: Badieeliwa.lan@azhar.edu.eg

This paper examines the manifestations of place in Fawzi Khader's poetry through his book entitled (Turn in My Circles), issued by the Egyptian General Book Authority in $r .10 \mathrm{AD}$, and the research reveals the patterns of place in his poetry, how he interacted with it, his vision of it and what he used of the spatial artistic image elements revealing So about an important area of creativity of the poe

Kay words: Literature - Poetry - Place - Fawzi Khader Manifestations- Turn in My Circles- badie eliwa. 
حوليتة كليت اللغت العربيت بإيتاي البارود (العدد الثالث والثلاثون)

تكتسـب دراسـة المكـان في الثـعر أهميـة خاصـة، لأنهـا تكثـف عـن

الظواهر النفسية والفكرية والثعورية لدى الثاعر وتكسبها دلالات فنية مختلفة.

فنجد لايه الاحتفاء بالمكان الطبيعي والصناعي، والمكان المخصص،

ويركز الضوء على المكان الأليف مثل الدار ، والمكان المعادي مثل البحر

الثائر، يتجول بصوره المكانية بين الأرض والسماء وما فيهما من أماكن وما بينهما مـن أجرام، ويرتحل في شعره بين المكان المعنوي الخيالي، والمكان الميتافيزيقي، رابطاً بين المكان والحركة والزمن. 


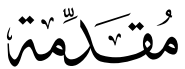

إنَّ حياة الإنسان زمن مقسَّم إلى مراحل، يقضيها الإنسان في أمكنة

مختلفة بحسب طبيعة كل مرحلة ومتطلباتها، وقد شغل المكان مسـاحة من التفكير البشري منذ أن وُجد الإنسان على الأرض، فقد صـار هناك تلازم بينه وبين المكان الذي كان يتذخل فيه لتعديله وفق احتياجاته لكي يحقق لـه الأمن الأن والراحـة، وتفاوتت ظـروف البيئة، فوجد أمكنـة أدخلت إلى قلبـه الاطمئنـان والسكينة، وأمكنة أخرى ملأت كيانه بالخوف والذعر ؛ لذلك ارتبط المكان بفكر الإنسان ومشاعره طوال حياته.

والثـعر واحـــ مـن أبـرز مظــاهر الأنشــة البشـرية التـي جسّــت الإحسـاس بالمكان، فسعى الثـعراء إلى توظيف الأمكنـة في إبداعهم الثـعري بما يتلائم مع حالتهم النفسية، ومـع ما ينطبع لدى كل منهم من رؤية مكانٍ معينِ أو تَذَكُّهر، فيصفه أو يصوّره في شعرٍ محمل بمعانٍ ودلالات وإيحاءات تضفي على المكان ما هو أكثر عمقًا من صورته الظاهرية وتتكيله الهندسي، فيجعل للمكان روحًا وانفعالًا وأحاسيس، وكما يعيش الإنسان في مكان فيؤثز في تنكيل ذلك المكان وتفاصيل بنائه ومحتوياته، كذلك يؤثر المكان في أدق تفاصسيل حيـاة الثـاعر وتفرعاتها بمـا يحملهـه مـن حوادث آنبّة في حياتـه أو ذكرياته الماضية؛ لذلك تتجلى انعكاسات متتوعة للتأثنير بين الثـاعر ومكانه، وعلى هذا يركز هذا البحث على العلاقة الحية بين الإنسان الثاعر والمكان. وقد اهـتم الدرس النقدي بالنصـوص الثـعرية اهتمامًا كبيـرًا، إلا أن المكان بوصفه عنصرًا أساسًا في النص الثعري لم ينل غير قليل من عناية الدراسـات النقديـة التي اقتصـرت على تتـاول المقدمات الطلليـة في القصـائد الجاهلية، بينما يوجد للمكان دور مؤثز وفعال في الثـعر العربي، ومنه الثعر المعاصر الذي يعد (فوزي خضر ) من أكبر مبدعيه ذوي المكانة المرموقة. ومن الدراسـات المهمـة للمكان في الثـعر المكان في شعر البردوني

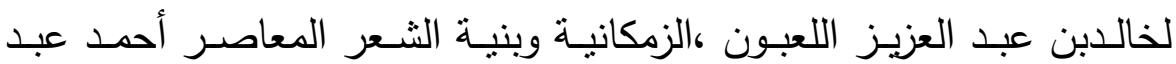


المعطي حجازي، المكن والزمان في العالم الكوني الحديث (ب.ك.و .ديفيس) ترجمة أدهم السمان، المكان ظاهرة في ديوان أغنيات للوطن للنـاعر قاسم أبو عين، لمحمد حسن الربعانية وغيرها. ويطهـح هذا البحث إلى الغور في الأعماق، واكتشـاف الأبعـاد التي تكثف تجليات المكان في شعر (فوزي خضر)، من خلال تعبيره عن الأمكنة التي عاش فيها أو التي مر بها في رحلاته أو تخيلها في ديوانـه (تدور بي دوائري)، حيث عبر الثـاعر عن وجودٍ فاعلٍ للمكان، يمكن تَلَمُّسُ حضوره وتفاعله بمـا يمتلكـه مـن قوة وتأثثير في عناصـر القصيدة مـن لغـة وموسيقا وتصوير، وقد اخترت أن أبحث في تجليات المكان في شعر (فوزي خضر)؛ لأنـه موضـوع لم يبحث من قبل بحسب علمي، وتتضـح فيـه براعـة الثـاعر وعمق تفاعله مع الأمكنة التي ذكرها في قصائده.

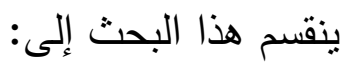

1- مقدمة، بها سبب اختيار البحث للدراسة، والخطة والمنهج وما حولها. r- التمهيد: التعريف بالثاعر.

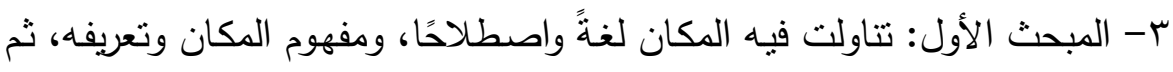

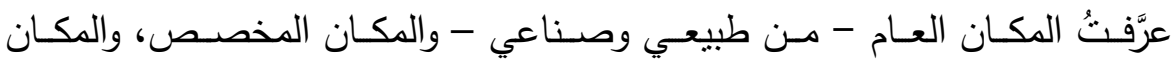
الخيالي، ثم تتاولت البعد النفسي للمكان والصلة بينه وبين الزمان، ثم عرَّجت على على على

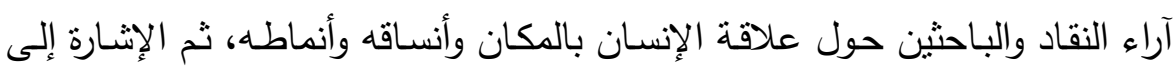

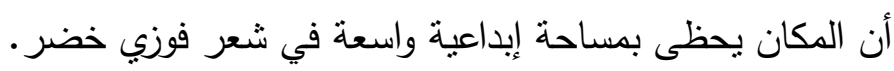

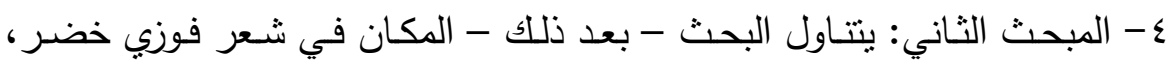

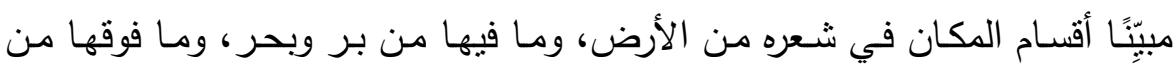

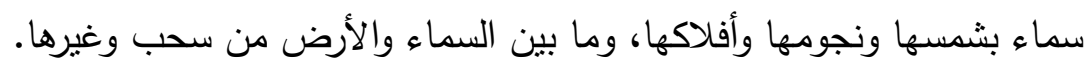

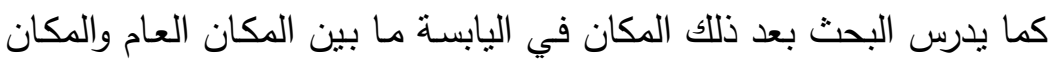

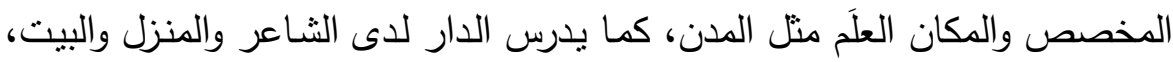
ويدرس المكان بوصفه مساحة للتفاعل الاجتماعي، ثم دور المكان في الصورة الفنية عند فوزي خضر ، وكيفية تتاوله المكان الطبيعي من فلاة وجبال وهضاب. 
حوليتة كليت اللغت العربيت بإيتاي البارود (العدد الثالث والثلاثون)

ويحظى البحر بنصيب في شعر فوزي خضر ؛ فالبحر هو مكان رحلاته بما

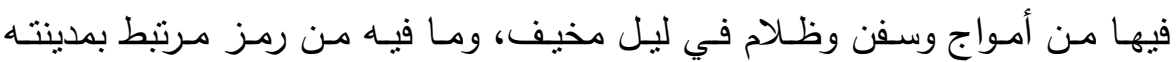

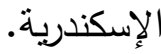

أما السماء بوصفها مكانًا فقد استخدمها الثاعر بلفظها، كما استخدمها بما تتتنمل عليه من شمس ونجوم وكواكب، والقمر منازله. واستخدم الثـاعر الفضـاء مكانًا بما يشتمل عليه من غيوم وسحب ونسيم ورياح بأنواعها المختلفة العاصفة منها والطيبة. وتتاول البحث - بعد ذلك - المكان المعنوي/ الخيالي عند الثـاعر، وهو المكان غير الموجود في الواقع، وإن كان يمكن إدراكه بالعقل والخيال مثل سجن

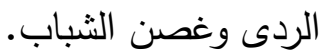

ويتجه البحث إلى دراسة المكان الميتافيزيقي عند فوزي خضر، وهو المكان الذي يتمثل في الجنة. ويشير البحث - بعد ذلك - إلى المكان والحركة والزمن وكيفية الجهـع بينهما في شعر فوزي خضر ، مما يؤكد أن الثناعر قد تفاعل في شعره مـع المكان بأنماطه المختلفة، وقدم المكان من خلال صورة لافتة ربط فيها بين الحركة والزمان

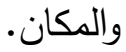

0- المبحث الثالث: دلالات المكان في شعر فوزي خضر

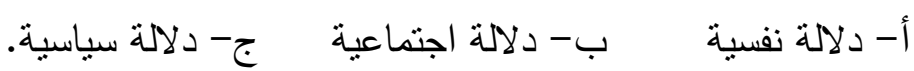
צ- ثم الخاتمة التي تعرض أهم نتائج البحث.

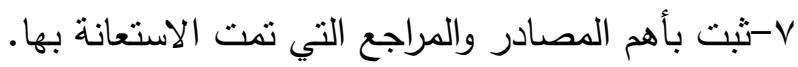
1-فهرس لموضوعات البحث. بله

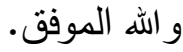

بديع فتح الاله عليوه

أستاذ الأدب والنقد المساعد

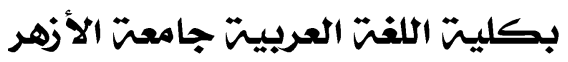




\section{التمهيد \\ التهريف بالشاعز \\ الدكتور فوزي خضر}

هو فوزي محمـود خضـر ، ولـد سـنة ـ 190 بالتوفيقيـة التابعـة لمركز ايتاي البارود بمحافظة البحيرة ،درس في كلية الآداب جامعة الإسكندرية حتى حصل بل على الدكتوراه سنة . . . F م انتقل إلى الإسكندرية وعاش بها ثم انتقل إلى مدينـة برج العرب الجديدة ،عمل في التحاليل الطبيـة ، كمـا عمل في مكتبـة الإسكندرية في قسم تحقيق المخطوطات ،سافر إلى ليبيا ،ثم سافر إلى المملكة

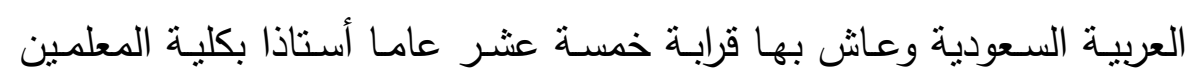
بالطـائف ثم أستاذا بكليـة التربيـة والآداب بجامعـة الطائف و مسنتـارا لمدير الجامعة ، ثم عاد إلى مصر ، والثـاعر يعيش حاليا بمدينة برج العرب أطال

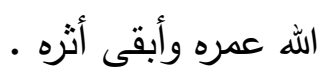
هو صـاحب البرنـامج الأشـهر بالإذاعـة المصـرية (كتاب عربي علم العـالم) والذي ظل يذاع لمدة تقارب الثناثين عاما وأكثر من خمسة آلاف حلقة واشترك التك بـه أغلب الفنانين العرب، وحصل على العديد من الجوائز الدولية وتم اذاعته في معظم الإذاعات العربية . كما حصل على العديد من الجوائز وشهادات التقدير من أهمها جائزة الدولة التشجيعية وجائزة الدولة للتفوق ،وجائزة الأمير عبد الله الفيصل الدولية للشعر

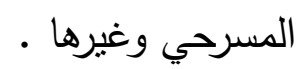
كتب عنـه معظم النقاد العرب منهم فـاروق شوشـة وصـلاح فضـل وعزالدين إسماعيل ضـلا عن دراسـات وبحوث اكاديمية كثيرة ،وهناك كتاب يطبع الآن عن كل ما كتب عن الثاعر في مصر وخارجها .

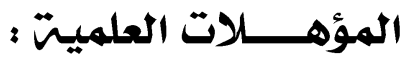

ليسانس الآداب - قسم اللغة العربية وآدابها واللغات الثرقية وآدابها

جامعة الإسكندرية 919 19 بتقدير "جيد" . 
حوليتّكليت اللغت العربيتشبايتاي البارود (العدد الثالث والثلاثون)

ماجستير - الموشـحات في العصـر الغرنـاطي 1990 - بتقدير

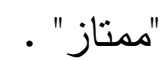

دكتوراه ـ عناصر الإبداع الفني في شعر ابن زيدون ... . بمرنبة

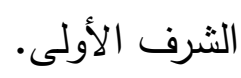




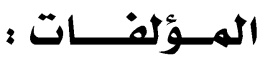

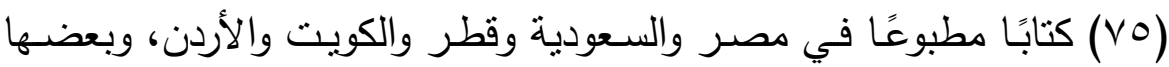
صدر لله أكثر من طبعة في أكثر من دولة وبيانها كالآتي:

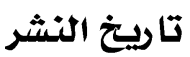

\section{المؤلفات}

أولاء : الد راسات :

إطلالة على الثعر السعودي - نادي جازان الأدبي - السعودية 1910

1990 أحمد بن ماجد أسد البحار . دار المعارف

$199 V$ مبادئ العَروض - مطبوعات أصوات معاصرة

1991

زرياب عبقري النغم - مكتبة ومطبعة الغد

1991 أعظم الكتب العربية في الفللك - المكتب العربي للمعارف

أعظم الكتب العربية في الصيدلة - المكتب العربي للمعارف

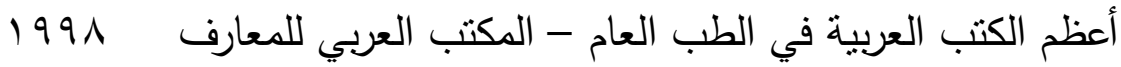

أعظم الكتب العربية في طب العيون - المكتب العربي للمعارف 1991

أعظم الكتب العربيـة في تخصصـات طبيـة مختلفـة - المكتب 1991 العربي للمعارف

1999 فهذ العسكر شاعر الحزن النبيل - مكتبة ومطبعة الغد

$r \ldots r$ شمس الإسلام تشرق في البلاد - الدار الثقافية للنشر

$r \ldots r$

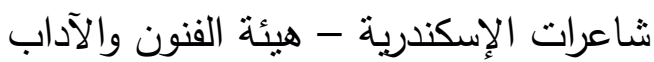

$r \cdot r$ ابن زيدون شاعر الحب المعذّب - الدار المصرية اللبنانية

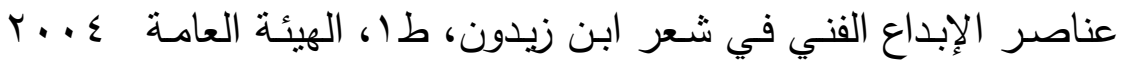
لقصور الثقافة

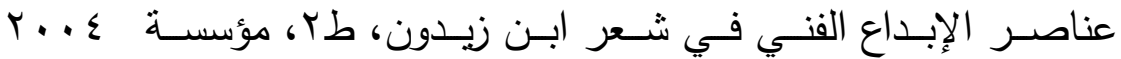
البابطين - الكويت

شعراء من الإسكندرية - دار الوفاء لدنيا الطباعة والنشر

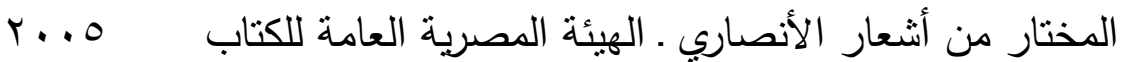


حوليتّ كليت اللغت العربيت بإيتاي البارود (العدد الثالث والثلاثون)

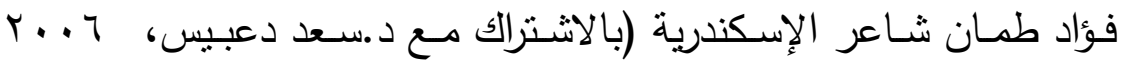
وعذاب الركابي)- دار السفير

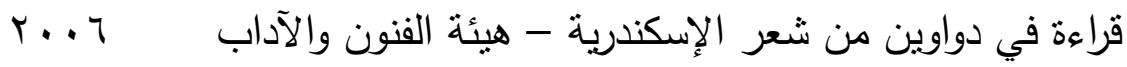

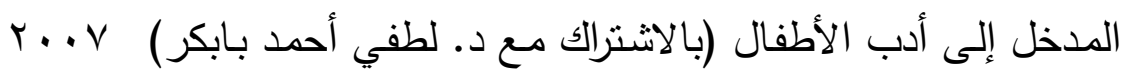
خوارزم العلمية للنشر والتوزيع - جدة - السعودية

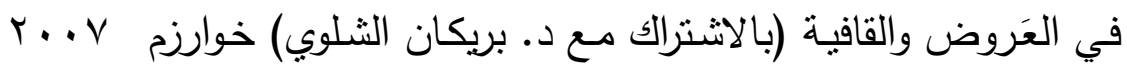
العلمية للنشر والتوزيع - جدة - السعودية

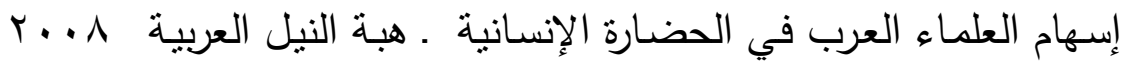

للنشر

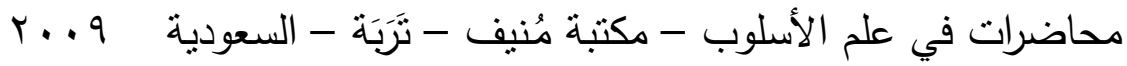

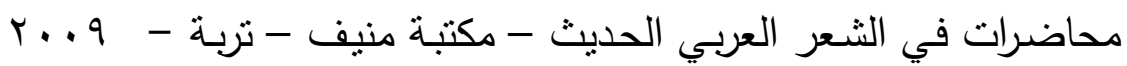
السعودية

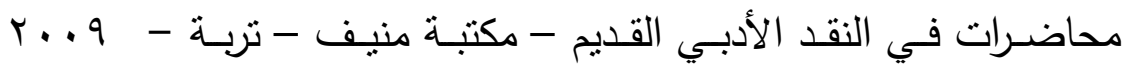
السعودية

إطلالمة جديدة على الثعر السعودي - نادي الطائف الأدبي السعودية

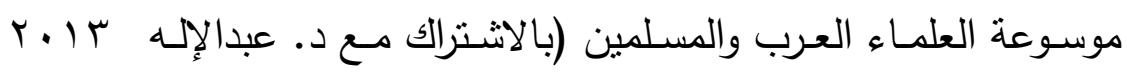
باناجه، د.عطا أبورية) - جامعة الطائف - المجلد الأول .

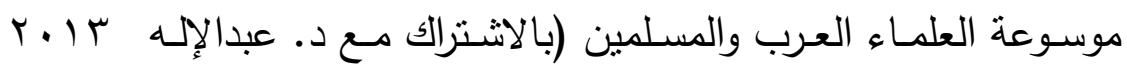
باناجه، د.عطا أبورية) -جامعة الطائف - المجلد الثاني .

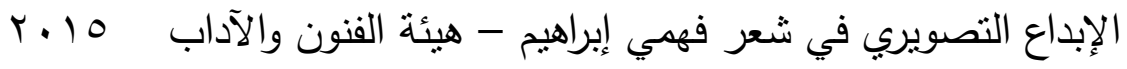
العلم العربي في حضارة الغرب - الدلتا للنشر - القاهرة

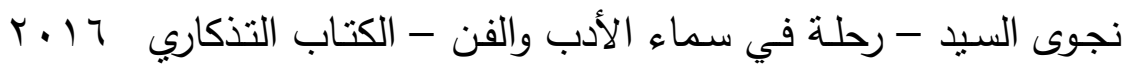
لأتيليه الإسكندرية - مكتبة ومطبعة الغد.

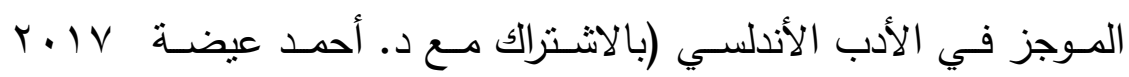


$19 \vee 0$

$19 \wedge \varepsilon$

1910

1910

$19 \wedge 1$

1991

1994

1997

1991

1999

$r \ldots r$

$r \cdot r$

$r \cdot 11$

$r \cdot 10$

$r \cdot 1 \cdot$
أغنية لسيناء (مشترك) ـ الهيئة المصرية العامة للكتاب التزحال في زمن الغربة . المجلس الأعلى للثقافة من سيمفونية العشق ـ المركز القومي للفنون والآداب فصل في الجحيم ـ الهيئة المصرية العامة للكتاب وََََهِيَةٌة إلىى الإسكندرية ـ مديرية الثقافة بالإسكندرية النيل يعبر المواسم ـ الهيئة المصرية العامة للكتاب الإنيا قطرات من شلال النار ـ الهيئة العامة لقصور الثقافة مسافات السفر ـ المجلس الأعلى للثقافة من سيرة الجواد المعاند ـ هيئة الفنون والآداب أمواج في بحر الحروف ـ اتحاد الكُتاب المصري التهري بركان يركض ـ الهيئة المصرية العامة للكتاب مكابدات ـ الهيئة المصرية العامة للكتاب مدائن المجهول - الهيئة المصرية العامة للكتاب تدور بي دوائري- الهيئة الهصرية العامة للكتاب

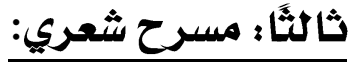
الثيخ الرئيس (ابن سينا) - المجلس الأعلى للنقافة

\section{رابعًا : كتب الأطفال:} أ / قصـص:

1919 عمر المختار (طبعة أولى) - دار الثرق - دولة قطر

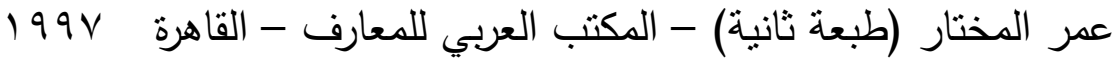
عبد الرحمن الداخل صقر قريش طا - دار الثرق - دولة قطر 1919

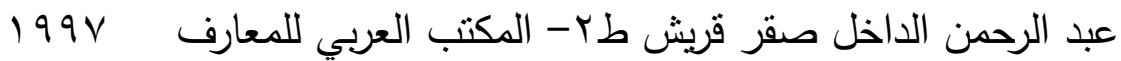
$199 \varepsilon$

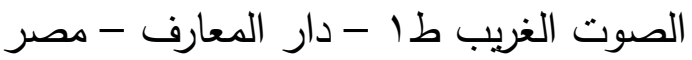


حوليتة كليت اللغت العربيت بإيتاي البارود (العدد الثالث والثلاثون)

$199 V$

1991

1991

1991

1991

1991

1991

1999

1999

1999

1999

1999

1999

1999

1999

1999

1999

أشــر الـرحلات إلىى جزيـرة العـرب - رابطـة الأدب الإسـلامي 999 العالمية . ط ا ـ دار البشير - الأردن

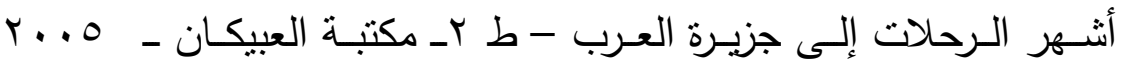
الرباض ـ السعودية

\section{ب/ مسـرحيــاث:}

الحمـار الحزين - شـركة أطفالنـا للإنتاج الإعلامسي - القاهرة / ب م . ب الرياض

$r \cdot r$ القرد ميمون - شركة أطفالنا للإنتاج الإعلامي 


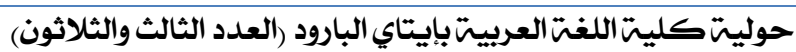

$r \ldots r$

$r \ldots r$

$r \ldots r$

$r \ldots r$

$r \ldots r$

r...
الكتاب المقلوب - شركة أطفالنا للإنتاج الإعلامي عودة - شركة أطفالنا للإنتاج الإعلامي نزهة في الغابة - شركة أطفالنا للإنتاج الإعلامي الجار التقيل - شركة أطفالنا للإنتاج الإعلامي الوعد الأكيد - شركة أطفالنا للإنتاج الإعلامي صباح جديد - شركة أطفالنا للإنتاج الإعلامي خامسًا : مؤلفات تمثيلين:

برنـامج خـاص عن صـلاح جـاهين - القنـاة الثالثة - تلفزيـون 1919

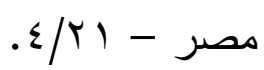

برنامج "اضحك مع" - القناة الثالثة - تلفزيون مصر ( • أ حلقة) عشرات المسلسلات والبرامج الإذاعية بمعظم الإذاعات العربية 


\section{المبحث الأول \\ هفهوم الاكان وأنواعه}

المكان في اللغنَّ:

المكان في أصل تقدير الفعل "مَفْعَل"؛ لأنه موضوع الكينونة، غير أنه لما كثر

أجروه في التصريف مجرى الفَعَال(').

والمكان: الموضع، والجمع أمكنة.. وأماكن جمع الجمع (؟).

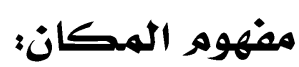

وُجدت فكرة المكان مع خلق الإنسان، ثم نمت وتطورت مع نمو الفكر

البشري وتطوره، فقد كان المكان هو المحور الرئيس الذي دارت حوله قصـة

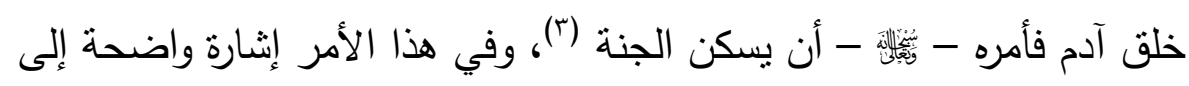

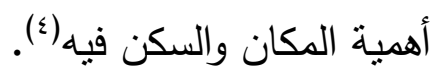

(1) عبد الرحمن الخليل بن أحمد الفراهيدي (ت:V0 الهـ)، كتاب العين، تحقيق: د. مهدي

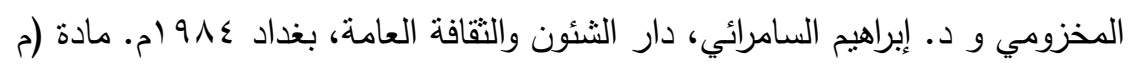

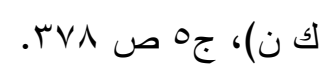

(Y) ابـن منظـور (أبـو الفضـل حمـال الـدين محمـد بـن مكـرم بـن علـي بـن منظـور

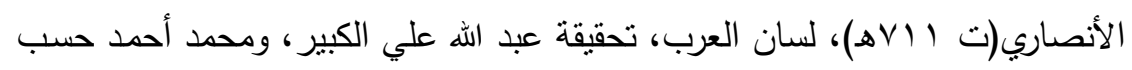

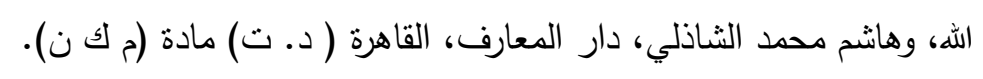

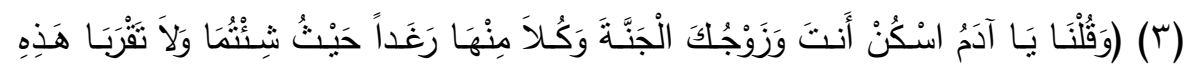

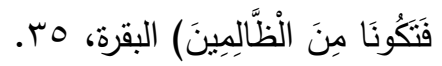

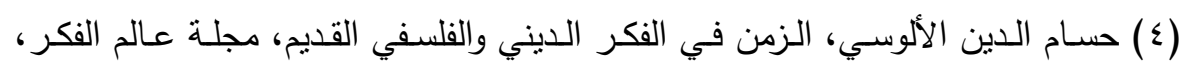

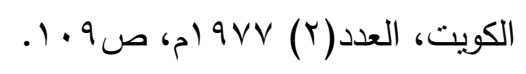


حوليتة كليت اللغت العربيت بايتاي البارود (العدد الثالث والثلاثون)

ثم أُنزل آدم وحواء - عليهما السـام - إلى الأرض (')، والأرض هي عالم الإنسـان ومكانسه الذي يـرتبط بـه منذ بدايـة الخلق (؟)، وهـي التي تمنح

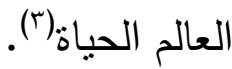

والأرض لا يقصد بها البر، وإنما يقصد بها البر والبحر ، وما يحيط بهما من فضاء، وما يظللها من سماء. تعريف المكان:

يوجد أكثر من تعريف للمكان، وإن كانت التعريفات كلها داخل إطار واحد يحيط بها، فالمكان مسـاحة ذات أبعـاد هندسية أو طوبغرافيـة تحكمها المقاييس والحجوم ويتكون مـن مـواد، ولا تُحدّد المـادة بخصائصـها الفيزيقيـة فحسب، بل هو نظام من العلاقات المجردة، فيستخرج من الأشياء الملموسـة مونة بقر ما يُستمد من التجريد الذهني، أو الجهد الذهني المجرد(ء).

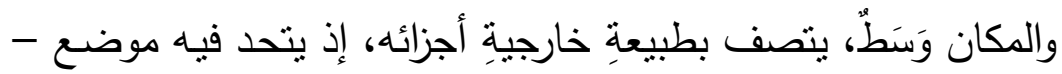
أو محل - إدراكاتتا، وهو يحتوي على كل الإمـادات المتتاهيـة، وهو نظـام تساوق الأشياء في الوجود، ومعيتها الخصوصية في تلاصق وممارسة وتجاور وتقارن (ن)

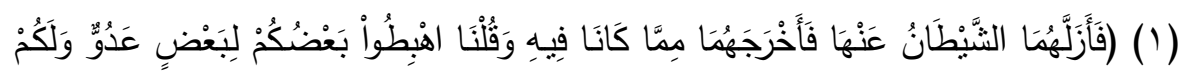

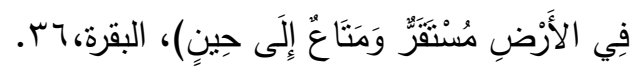

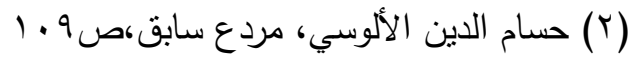

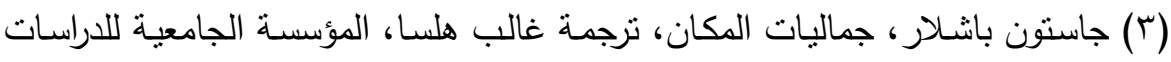

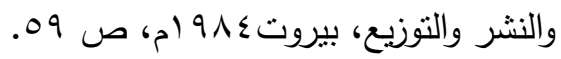

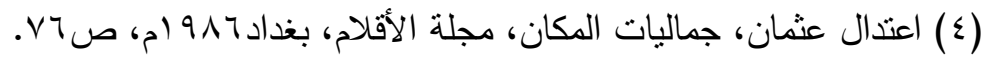

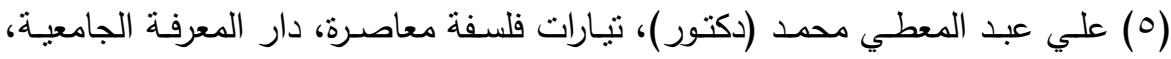

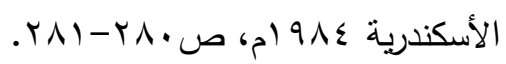


حوليتة كليت اللغت العربيت بإيتاي البارود (العدد الثالث والثلاثون)

وهذا يعني أن المكان في الثـعر لا يقتصر من حيث كونـه أبعادًا

وحجومًا، بل هو نظام من العلاقات المجردة تتصل بجوهر العمل الفني (').

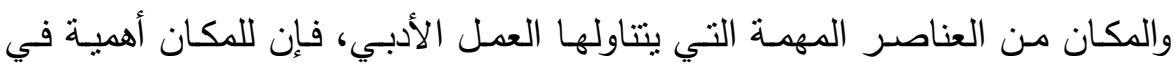

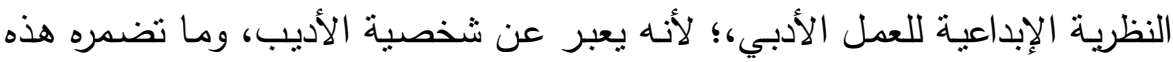

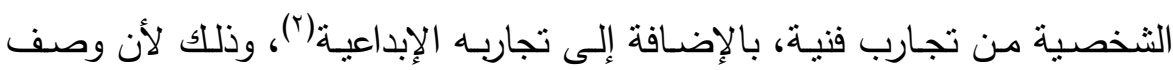

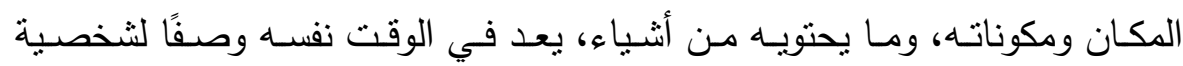

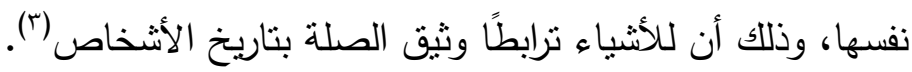

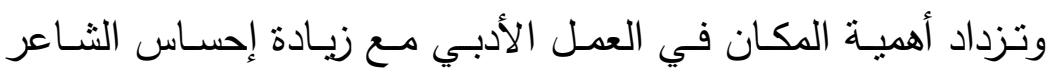

بالدور الذي يقوم به، وبما يوصله من رؤى وأفكار ضمن عناصر تكوينه.

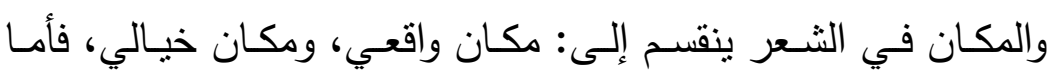
المكان الواقعي فهو يشتمل على الآتي: أولا: المككان العاهر: وهو مكان غير محدد، وينقسم إلى: 1- المكان الطبيعي: وهو المكان الذي لا يتدخل الإنسان في صنعه مثل: الأرض بمـا فيها من وديـان وصـحارٍ وجبال وغابـات، وبحسار وأنهار

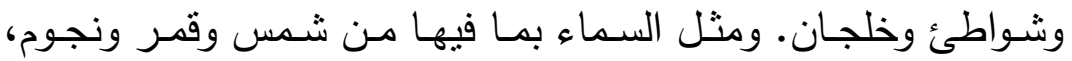
والفضاء وما يسبح فيه من سحب وغيوم، وما يضم من طيور ورياح. r- - المكان الصـناعي: وهو المكان الذي يتدخل الإنسـان في صـنعه وإنشائه، مثل: المدن والقصور والقلاع، والمساجد والمآذن والقباب، والثوارع والبساتين والحقول.

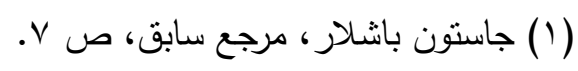

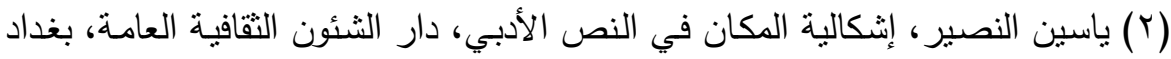

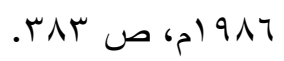

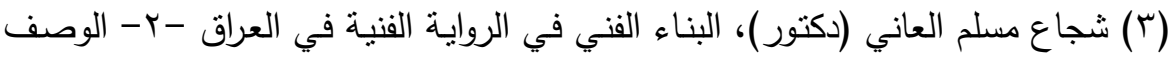

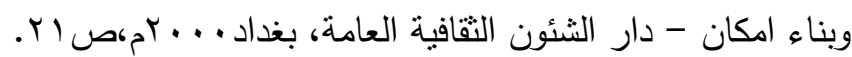




\section{ثانيا: المكان المخصص:}

وهو المكان المحدد، مثل: وادي النيل، وجبل عرفات، وصحراء النفود، والخليج العربي، ومثل شـس أغسطس، وقمر النصف مـن شعبان، والنجم سهيل، وريح الصبا... وما شابه ذلك. وأما المكان الخيالي فهو مكان يبتداعه خبال الثاعر ، يضم تجربة عاطفية وفكرية تجري في عالم غير عالم الواقع، وعالم خيالي بحوادث خيالية، لكنها تحدث في مكان محدد، يختاره الثاعر من مخزون معايشته للأمكنة.

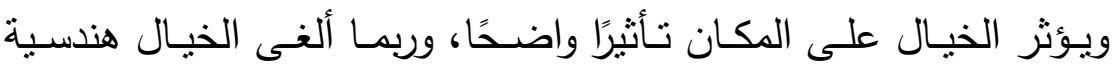
المكان ليحل محلها تفاعل الثـاعر مـع جزئيات أخرى، وربمـا امتزج الخيال ببعدٍ موضوعي واجتماعي بحسب تصورات الثاعر للمكان، وما يثيره في نفسه

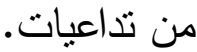

والثاعر المبدع يمتذ خياله وتتجلى قدرته الإبداعية على خلق أماكن فنية من خلال النص الإبداعي بوصفة بنية ثابتة موازية لعالم الواقع، بما يكتنزه من

$$
\text { دلالات وأبعاد فكرية وجمالية(') }
$$

ومن المهم أن نشير إلى أن المكان الثـعري لا بعتمد على اللغة وحدها، إنما يحكمه الخيال الذي يثكّل المكان بواسطة اللغة، على نحو يتجاوز قثرة الواقع إلى مـا قد يتتاقض مـع هذا الواقع، غير أنه يظل على الرغم من ذلك واقعًا محتملًا، إذ إن جزئياته قد تكون حقيقة، ولكنها تدخل في سياق حلميّ،

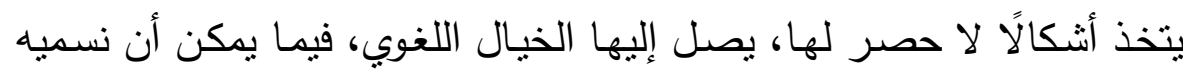

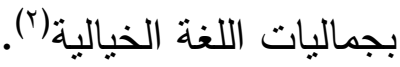

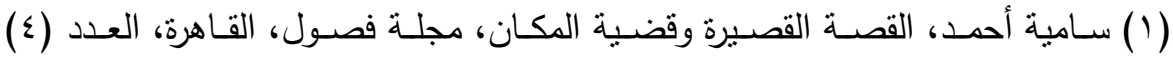

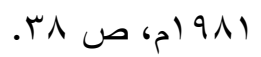

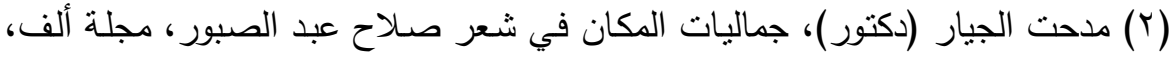

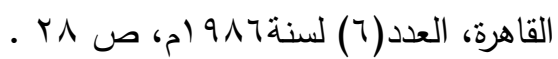




\section{البعد النفسي للمكان:}

تُمنّلّل الأمكنة حضورًا نفسيًا فعَّالا لدى الشعراء، يتجسد في قصائدهم عبر حالة من التفاعل النفسي مـع المكان، وهذه الحالة هي حالة داخلية، لا تشبه أي حالة أخرى.. إن حلم اليقظة ينقل الحالم خارج العالم المباثـر إلى عالم

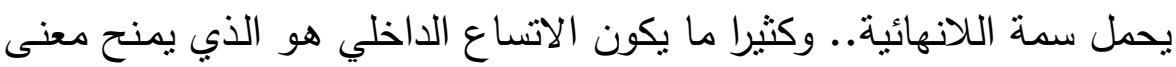
حقبقًا لبعض التعبيرات المتعلقة بالعالم المرئي (').

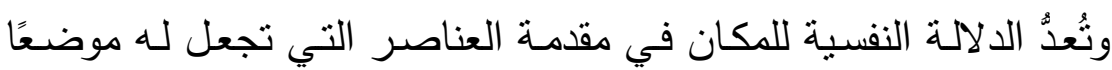

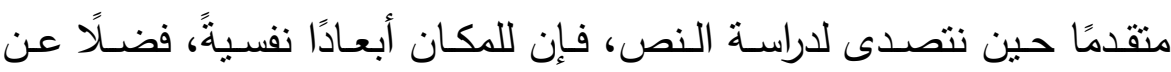
وظائفه الفنية وأبعاده الاجتماعية والتاريخية والعقائدية التي ترتبط به ولا تفارقه،

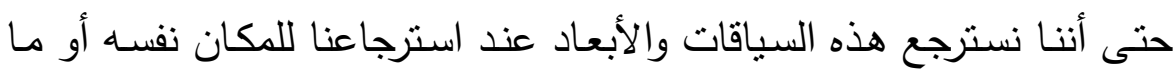

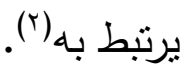

\section{الزمن والمكان:}

توجد صلة وثنقة بين الزمان والمكان، فالزمان هو لحظة وقوع الحدث، والمكـان هـو موقـع حدوثـه، وإذا كـان الـزمن يمثنل الخـط الذي تسـير عليـه الأحداث، فإن المكان يظهر على هذا الخط ويصاحبه ويحتويه، فالمكان هو الإطار الذي تقع فيه الأحداث، وهذا اختلافت في طريقة إدراك الزمن وطريقة

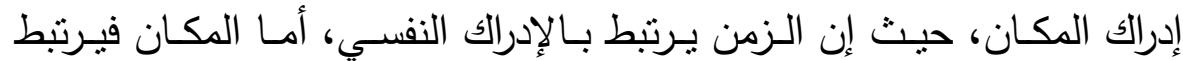
بالإدراك الحسي (־)، فالعلاقة بين الزمان والمكان علاقة جوهربية متبادلة، وتوجد

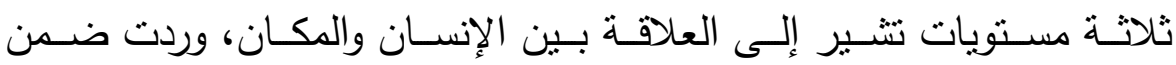
مصطلحات النقد السيميائي هي:

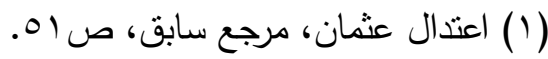

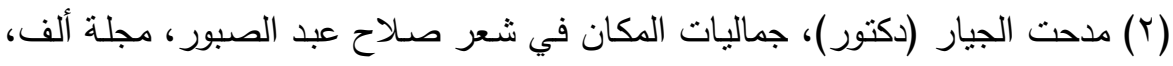

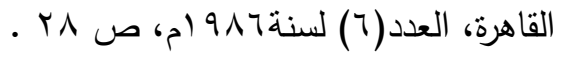

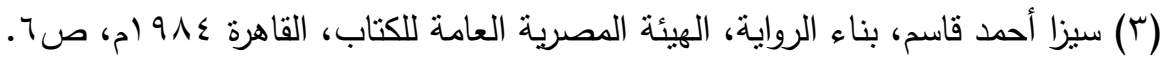




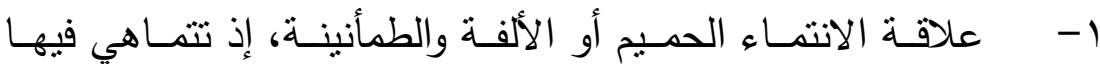

الثخصية مع مكانها على أثند ما يكون الارتباط الوثيق معه.

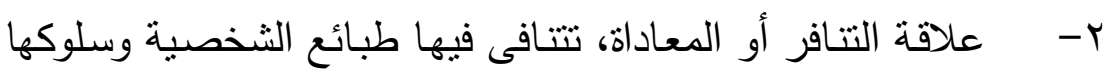

مع المكان، لشعورها معه بالغربة الجسدية أو النفسية أو الفكرية.

r- علاقة الحياد، هي علاقة السطحية التي غالبًا ما يفرزها اتصـال

الغرباء بالمكان الذي يقيمون فيه(').

أنساق المكان وأنماطله:

اختلف النقاد والباحثون في تحديد أنماط المكان فلم تكن النظرة واحدة

بخصوص نمط معين أو عدة أنماط يؤول إليها النص الأدبي بل كانت فكرة

النص ودلالته متتوعة بتتوع أنساقه وتتوع مؤثراته الداخلية والخارجية.

ومسن تقسيمات المكـان قسـم الناقــ ياسـين النصـير المكـان إلـى نـوعين

رئيسين، هما:

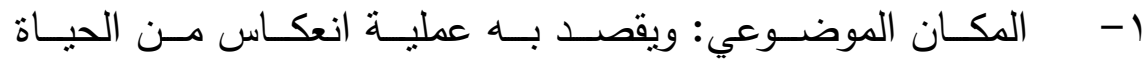

الاجتماعيـة على أسـاس أنسه يبنـي تكويناتـه مـن الحيـاة اليوميـة

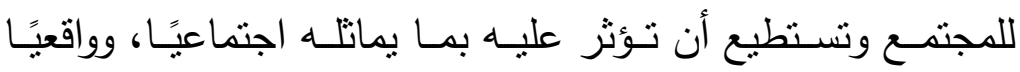

أحيانًا.

r- المكان المفترض: وهو عملية افتراضية عن طريق التخيل، الذي

تتشكل أجزاؤه وفق منظور مفترض، وهو يستمد بعض خصوصن فئصسه

من الواقع إلا أنه غير محدد وغير واضح المعالم(؟).

أمّا الناقد غالب هلسا فقسم المكان وفق ما جاء عند جاستون باشـلارآ إلى إلى

ثنالثة عناوين، هي: - ت من

WWW.AWudam.org rV9 (1) مصطلحات النقد السيميائي (1)

(Y) ياسين النصبر ، الرواية والمكان، منشورات وزارة الثقافة والإعلام، الجمهوريـة العراقية،

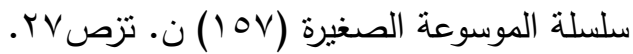


حوليتّكليت اللغت العربيتشبايتاي البارود (العدد الثالث والثلاثون)

- المكـان المجـازي: وأراد بـه مكانًا غيـر مؤكـد، إنمــا هـو أقـرب إلـى

الافتراض. - اض

- - المكان الهندسي: وهو المكان الذي يعرضسه الراوي من خلل وصف أبعاده الخارجية بدقة بصرية، وفي هذا النوع يُحرم القارئ من استخدام خياله، وهو بذلك يقتل الخيال ويتحول المكان فيه إلى درس هندسي. - المكان كتجربة معايشـة: وهو مكان عاش فيه المؤلف وبعد أن ابتعد عنـه أخذ بعيش فيـه بالخيـال، فأثز في أدبـه كتجربـة داخل العمل

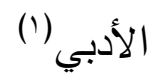

أمّا تقسيمات بروت للمكان فكانت كالآتي:

1- المكـان الأصـل: وبمثثل - عـادة - مسـقط رأس المؤلف ومحل العائلة.

r- - المكان الـوقتي: وهـو مكـان عرضـي ووقتي وقـد أطلـق علبـه غريماس مصطلح (المكان التشربحي الحاف) وهو مجاور للمكان المركزي.

ب- - المكـان الـي يقع فيـه الإنجـاز أو الاختيـار الـرئيس وهـو عند غريماس (باللامكان)؛ لأن الفعل المغير للذات والجوهر لا بمكن أن يتجسم في إطار معين، لذا فإن مكان الفعل هو اللامكان.

أما شجاع العاني فيقسم المكان إلى أربعة أصناف مستفيدًا من الثنائيات. ا- - المكان المسرحي: وبتميز بأنه مكان مجازي أو افتراضي على أنه إسه سلبي تابع للأحداث والثخصيات، لا يتفاعل معهما ولا يؤثز في صباغة الحبكة.

r- - المكان التاربخي: وهو المكان الذي لا ينفصل عن الزمان. 


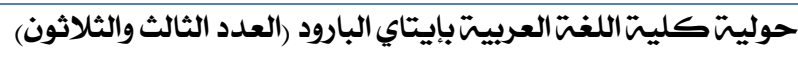

r- المكان الأليف: كل مكان يثير الإحساس بالألفة من حيث العيش والألفة والحنان بحيث يشكل هذا المكان مادة لذكرياتتا. ع - المكان المعادي: وهو المكان الذي يشعر الفرد فيه بالضيق وعدم الانسجام مع البشر ويتمثل ذلك في السجون والمعتقلات. كما درس حميد الحمداني المكان الروائي في كتابه (بنية النص السردي) وصنف الفضاء الروائي إلى ثناثة أنواع:

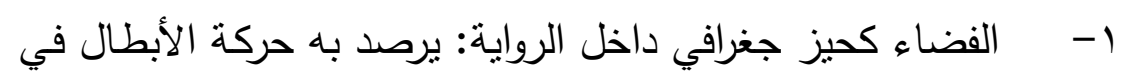

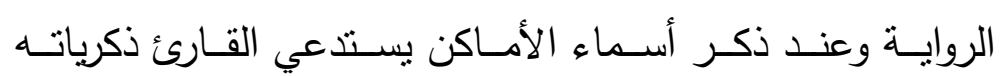
لاستحضار تلك الأماكن. r- الفضـاء كرؤيـة: وهو عمليـة السيطرة على مجريـات الروايـة من لاهن خلال إضفاء الكاتب رؤيته في عملية السرد.

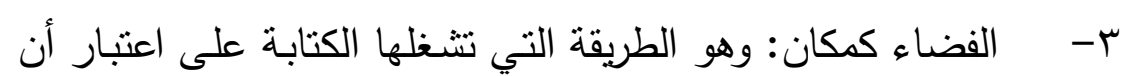
الحرف يحتل حيزًا مكانيًا من الورقة أي كعتبات نصية تبدأ من

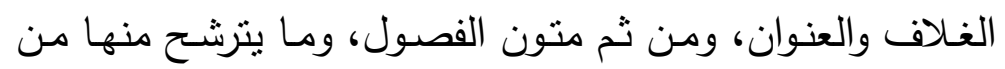

$$
\text { دلالات ('). }
$$

أمّا دراسـة حسن بحراوي فقد جاءت عن المكان باعتباره عنصرًا تتشكل منـه الروايـة إلى جانب (الزمان والثخصية) سماه الفضـاء الروائي وجعله عنصرًا شكليًا فاعلًا في الرواية، فقد جاءت وفق المحاور الآتية: ا - أماكن الإقامة الاختيارية (البيوت). r- أماكن الإقامة الإجبارية (السجن).

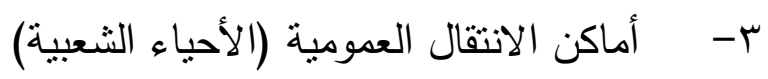
ع - أماكن الانتقال الخصوصية (المقاهي)

(1) نقلا عن: محمد عزام، فضـاء النص الروائي، مقاربـة بنيويـة تكوينيـة في أدب نبيل

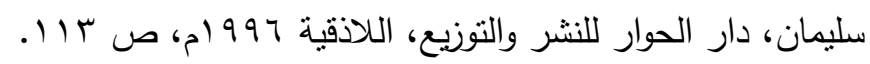


حوليتة كليت اللغت العربيت بإيتاي البارود (العدد الثالث والثلاثون)

ويظهر التقابل بين الأنماط المكانية، وفق دواعي بقاء بعض الأمكنة بـا أسماء عبر تصور أماكن واقعية، لكي يوجد أمكنة متخيلة نؤدي دور الإيهام

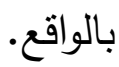

من هنا فإننا نستطيع أن ندرج مجموعة من التقابلات المكانية دليلًا على حضـور البعـد التركيبـي الذي تتولـد منـه الــلالات وهذه التقابلات المكانيـة

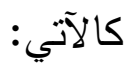

$$
\begin{aligned}
& \text { إل أماكن الإقامة. } \\
& \text { أ- الاختيارية (البيوت). } \\
& \text { r } \\
& \text { أ- - المقهى. }
\end{aligned}
$$

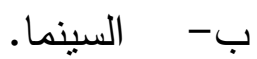

$$
\begin{aligned}
& \text { ج- المطعم. } \\
& \text { ץ - المحلات العامة (المكان المفتوح). }
\end{aligned}
$$

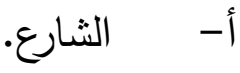

$$
\begin{aligned}
& \text { ب- المحلات. }
\end{aligned}
$$

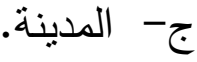

$$
\begin{aligned}
& \text { ع -الأماكن الطبيعية. } \\
& \text { أ- الحدائق. } \\
& \text { ب- ب البحر (') }
\end{aligned}
$$

ويمكن القول: إن النظر يتجه إلى المكان كثيء يحمل أكثر من دلالة

أو قيمـة حضـارية، تتشكل تبعًا للمعطيـات الثقافيـة للمجتمع في الفترات

( (1) حسن بحراوي، بنية الثكل الروائي، المركز الثقافي العربي، بيروت •99 ام، ص اء. 
حوليتّ كليت اللغت العربيت بإيتاي البارود (العدد الثالث والثلاثون)

الزمنيـة المتعددة، وعلاقة الثـاعر بالمكان متعددة، وتستحضـر الواقعي،

$$
\text { والخيالي والوهمي ('). }
$$

ويحظى المكان بمساحة إبداعية واسعة في شعر فوزي خضر الذي ندرس تجليات المكان في قصائده من خلال ديوانه (تدور بي دوائري) الصـادر عن الهيئة المصرية العامة للكتاب سنة 10 • بام.

(1) جريدي سـليم المنصـوري الثبيتي، شـاعرية المكان، مطـابع شـركة دار العلم للطباعـة

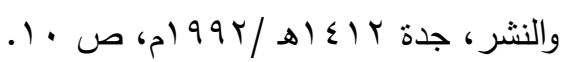




\section{المبحث الثاني}

\section{الاككان في شعر فوزي}

\section{ديروان (تدور بي دوائري) نموذجةً}

عتبت الديوان نظرة فنيتتا:

يضـم الديوان الذي بين أيدينا OV قصسيدة منها مه قصسيدة تفعيلة، بعضها مقطعة: قد تكون المقاطع كلها من بحر واحد، وقد تكون من أبحر مختلفـة، وقـد يتخللهـا مقطـع قصـير مـن أبيـات مـن البحسور المركبـة. أمـا القصيدتان الأخريان فقد اتخذتا الثكل العمودي إحداهما من مشطور البسبط، حيث يكون البيت شطرًا واحدًا منقسمًا إلى شطرين، والأخرى عبارة عن مقطع من ثلاثة أبيات من الكامل، وكل هذا التتوع الموسيقي يؤدي إلى ثراء ونتوع في الرؤية الثعرية، أو أن الرؤية الثعرية المتتوعة هي التي فرضت هذا الثراء الموسيقي. وقد احتل بحر الخبب المرتبة الأولى في هذا الديوان (1 ا قصيدة) ثم المتقارب ( • قصائد) ثم الرجز (^ قصائد) منها قصبدنان على موحد الرجز ، حيث يجيء البيت عبارة عن تفعيلة واحدة، فجاءت إحداهما بالفعل على تفعيلة واحدة، والثانية من مقاطع يأتي في ختام كل مقطع تفعيلتان، ثم بحر الرمل (ع قصسائد) ثم المتدارك والكامـل (قصسيدنان لكل منهمـا) ثم الوافر (قصيدة واحدة)، ثم يضـاف إلى ذلـ القصـائد المقطعيـة التي تغيـرت فيهـا الأبحـر فقصسيدة (اقتسم الغربـاء ثيابي) جاءت من بحر المنقارب، وجاء في أثنائها مقطع من ثلاثة أبيات عمودية على بحر الخفيف، وقصبدة (ثلاثة وجوه لهذا الغصـن) مـن ثلاثتة مقاطع جـاءت كالتالي: (خبـب- رجز -خبـب) وقصـيدة (الخروج مـن الثـق ) مسن خمسـة مقـاطع (رجز كرجز -رمـل كرمل -رمـل) وقصبدة (أغنية حب) جاءت على المتقارب وفيها مقطع صـغير من الوافر، وقصيدة (عفراء وحكايـة المـوت) مسن أربعـة مقاطع مسن الرجز وبيدأ المقطع الرابـع بمقطع طوبـل: بـين قوسين: مـن الخبب وقصسيدة (العيد المنسي) مـن 
المتقارب، لكن المطلع يبدأ بجملـة من الرجز ، ثم جملة من الخبب، كتقاسيم

حرة قبل ثم يأتي المتقارب وبستمر حتى نهاية القصيدة('). ولعل عتبـة الديوان (تدور بـ دوائري) تضـعنا في عمق الاغتراب

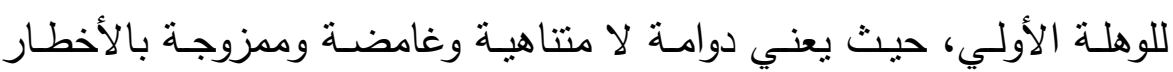
المحتومة، والدوائر هي الهزائم والدواهي وهي تدور بـه مما يعني أنها مستمرة في الدوران؛ لتتنهي بـه إلى النقطة نفسها التي بدأت منها، وإذا كان الثـاعر يضعنا في حالة اغترابية منذ عتبة عنوان قصيدته من الهاوية، فإنه قد وضع عنبة أخرى بعد العنوان عبارة عن مقطع للثاعر نصيب بن رباح هذا المقطع يذوب فيه الثاعر وجدانًا وصبابة؛ ليصنع حالة من الحب والثجن قبل قصيدة ممتلئة بالحب والثـن تطرح قضية الحب، التي هي بضـاعة الثـاعر ، مـع المادة التي هي ليست بضاعته، فإما أن تفيق الحبيبة وإما الهاوية، فهي حالة جدلية بين المادة المسبطرة على عالمنا وبين الحب الصـافي. نتتصر للحب الذي يمكنه أن يخرج الناس من الهاوية، يقول الثاعر في مطلع القصيدة:

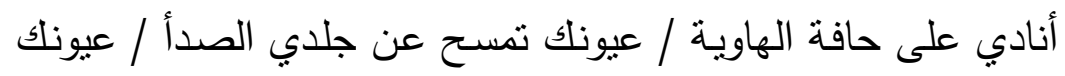
نيل يفيض / ويجتاح في ركضه الظمأ / مدينة عشق / تغازلني في الصباح نوافذها /وتسامرني في المساء مصابيحها /وتقاسمني حجرتي الخاوية /أنادي عليك من الهاوية.

ثم ينتقل الثـاعر إلى سمة عصرنا المادي، فبدلًا من أن يكون المال لحماية الحب صار هو المسيطر ؛ مما أفزع الثاعر حيث يقول في القصيدة:

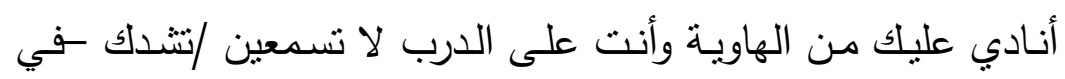
واجهات المحال - الفساتين /تجذب عيني -خلف الزجاج- الحقائب والأحذيه/

(1) حين انفصل الفارس عن جواده فوزي خضـر في ديوان (تدور بي دوائري ) عبد

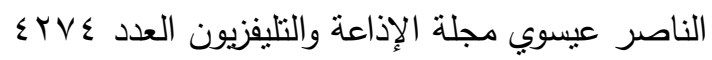


تمدين عينيك للعطر /مبتسمًا في القوارير/ تبتسمين لوجه المساحيق/ثم إذا ما دخلت الحدائق:/لا تجدين بها الواجهات ويضحك في وجهك الثجر • ويفند الثـاعر تلك الجدلية بين الحب والمـادة؛ حيث إن الحب بديل عن التشيؤ الحادث بسبب هذا الجفاف المادي، فيقول: أحبك / حقلي أثنماره ليست تقطف من واجهات المحال / أحبك/ كيف نسيت تاريخنا / جعدت شفتاي كما جعدت ذات يوم يديك / حبك من كلماتي

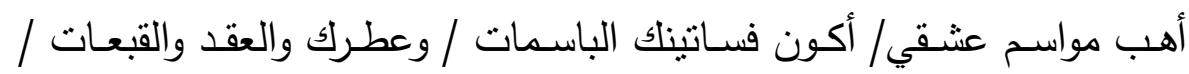

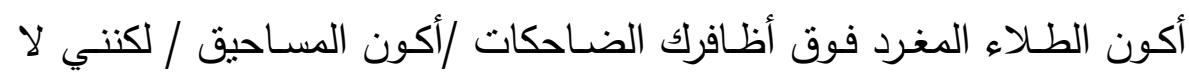

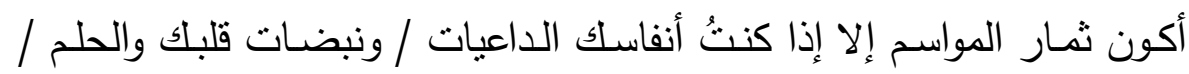
والخطـوة الآتيـة / أفيقي أكن حقلك المرتجـي / أو دعينـي أحبـك مـن هـذه إله الهاوية. وقد يتخذ الاغتراب جدلية ببين ثنائية (النصر -الجرح) كما في قصيدة بعنوان (لهذا)، حيث يقول الثاعر: لن أكتب للك شيئا هذا العـام /لا شـيء جديد/ لا زلت ألت أعد العـدة

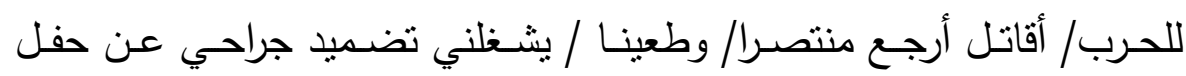

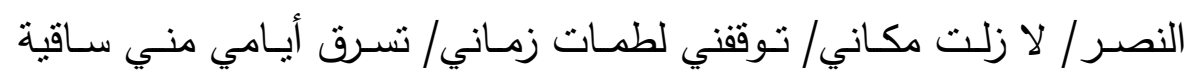
العمر/ لا تمنحني ما يكفيني من ري/لم أقبض من هذي الريح سوى كفي/لم لم

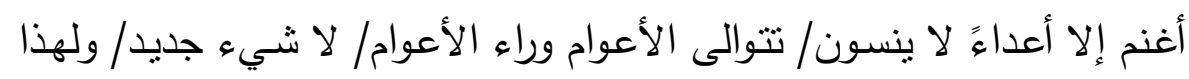

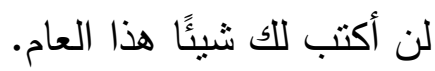
والثاعر يقف ضد الحرب من خلال جدلية الحب والحرب، كما في قصيدة (النوافذ مفتوحـة في انتظار الحلم)، وهو أيضـا ضد التشيؤ كما في هي

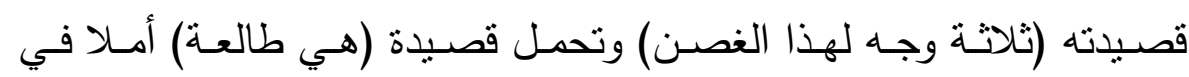
استعادة القدس، وهو يطرح في كثير من نصوص الديوان الأمل وسيلة للقضاء

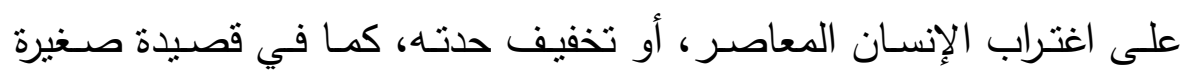
بعنوان (ما زالت) وكما في قصيدة (تأتي لحظة ميلاد) حيث انفصل الفارس 
عن جواده فأحدث ذلك حالة اغترابية، ولكن الثاعر لديه الأمل والرغبة الدائمة في الرجوع والاتصال وعودة الأمور إلى نصابها.

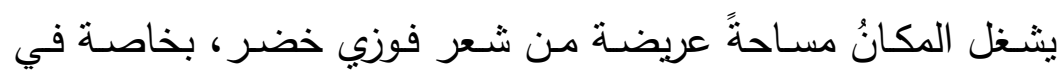
أحدث دواوينه (تدور بي دوائري)، فمنـه المكان الواقعي وينقسم الى المكان العام والمكان المخصص، والمكان الخيالي والمكان التاريخي، والمكان الأليف والمكان العادي، وغير ذلك.

ويتمنل المكان في الأرض بكل ما فيها وما عليها وما فوقها، فتعامل فوزي خضر مـع المكان الذي في البر، والذي في البحر، والمكان الذي في

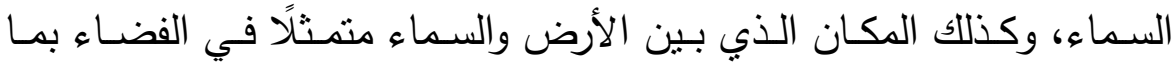
يحتوي عليه من رياح وطيور ، وما يضمه من آثنار علويـة(') تشـل طبقات الجو؛ لذلك سوف نتتاول بالدراسة المكان عند الثاعر حسب التقسيم التالي: ثنانيًا : خيالي

$$
\text { المكان قسمان: أولاً: واقعي }
$$

\section{أولًا : المكان الواقعي وينقسير قسمين:}

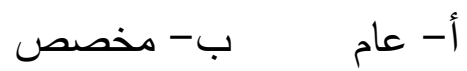

ومن ثم ينقسم المكان العام قسمين: 1 - طبيعي - صناعي

\section{ثانيًا: المكان الخيالي.}

هذا إجمالًا، أما التقصيل فالمكان الواقعي يشتمل على الآتي:

(1) الآثار العلوية مصطلح تراثي قديم يشير إلى الظواهر الجوية التي تحدث في الغلاف

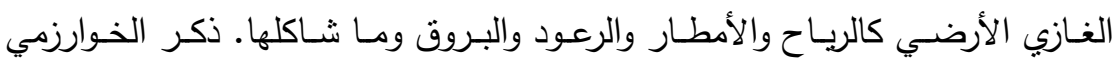
الكاتب المنوفى سنة r

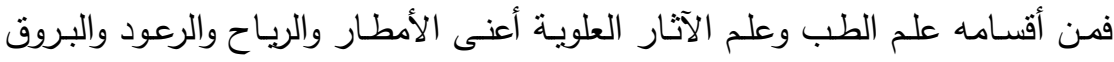
ونحوها وعلم المعادن والنبات والحيون وطبيعة كل شيء مما تحت فللك القمر ـ وأقدم المؤلفات في هذا العلم كتاب الآثار العلوية لأرسطو طاليس ويسنع علم الآتار العلوية في الوقت الحاضر ضمن علم الأنواء الجوية، عبد الأمير مؤمن، قاموس دار العلم الفلكي، دار العلم للملايين، بيروت ج +. بأم. 


\section{الأول: المكان العاهر:}

وهو مكان غير محدد، وينقسم إلى

1- المكان الطبيعي: وهو المكان الذي لا يتدخل الإنسان في صنعه

مثنل: الأرض بمـا فيهـا مـن وديـان وصـحاري وجبـال وغابـات،

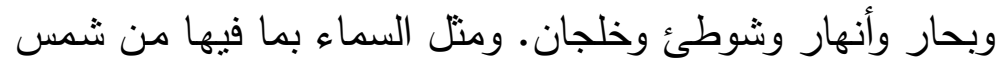

وقمر ونجوم، والفضاء وما يسبح فيه من سحب وغيوم وما يضم

$$
\text { من طيور ورياح. }
$$

r- المكان الصناعي: وهو المكان الذي يتدخل الإنسان في صنعه

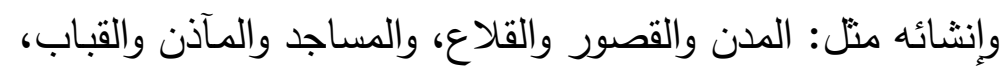
والثوارع والبساتين والحقول.

الثاني : المكان المخصص: وهو المكـان المحدد مثنل وادي النيـل، وجبـل عرفـات، وصـحراء النفود،

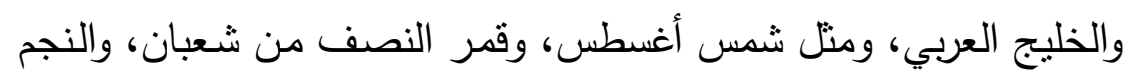
سهيل، وريح الصبا... وما شابه ذلك. ثانيًا : المكان الخيالي فهو مكان يبتدعـه خيال الثـاعر ، يضــ تجربـة عاطفية وفكريـة تجري في عالم غير عالم الواقع، وعالم خيالي بحوادث خيالية، لكنها تحدث في مكان محدد، يختاره الثاعر من مخزون معايشته لألمكنة.

\section{أولا : المكان الواقعي :}

بدايةً استخدم فوزي خضر لفظة المكان في أكثر من قصيدته في ديوانه (تدور بي دوائري، منها قوله في قصيدته المعنونة بـ (تلاثنة وجوه لهذا الغصن) : وكان أن تغيَّر الزمان والمكان ونبتت مدينة 
حوليتة كليت اللغت العربيت بايتاي البارود (العدد الثالث والثلاثون)

أصبحث غصنًا بافعًا (1)

وفي قصيدته (هموم جبل) وهي قصيرة يذكر لفظ (مكان) خمس مرات، منها قوله: أوقن أن مكاني موجود/يتمنى قربي/أسعى في العمر إلبه/ويومًا يهديني لمكاني ربي يومًا يهديني ربي (r) وفي قصيدته المعنونه بـ (لهذا) يقول :

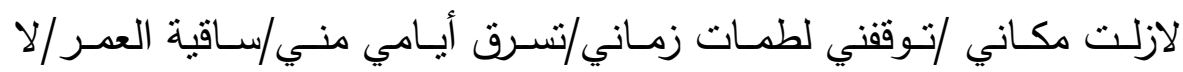
تمنحني ما بكفيني من ريٍّ

أمسا استخدامه للمكان فكان فيـه مبدعًا حيث دار بينهـه وبين المكان أحاديث، وتفاعل مـع المكان حسًا وشعورًا، وناغم بين الزمان والمكان، وذاب في المكان وذاب فيه المكان، فشكى منهه، وشكى إليه، وشكاه لغيره، وأحبـه وكرهـه، وتقبله ورفضـه، وغير ذلك من التفاعل الذي جعل للمكان في شعره هذه الأهمية التي لا تغفلها العين، وخاصـة أن الثـاعر قضى مدَّةً طويلة من ونس

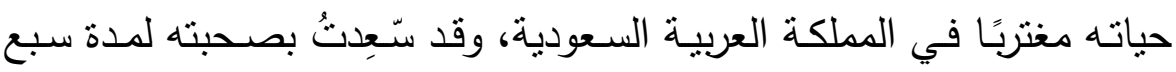

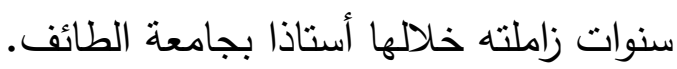
وقد اشتمل المكان الواقعي على مكان طبيعي ومكان صناعي، وقد قسمت المكان الطبيعي إلى: 1- مكان طبيعي أرضي عام طبيعي مثل الأرض والصحراء الخ r- مكان صناعي: فمثل البيت القصر المدينة الثارع الخ أرضي.

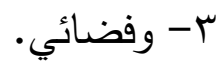

( (1) ديوان تدور بي دوائري د. فوزي خضر الهيئة المصرية العامة للكتاب 10 • ب م.

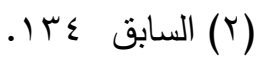




\section{(1) المكان الواقعي العاهر الطبيعي الأرضي:

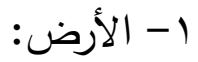

ذكر فوزي خضـر الأرض كمكـان ينتمـي إليـه في أكثر مـن عشـرة مواضع في ديوانه (تدور بي دوائري) منها قوله:

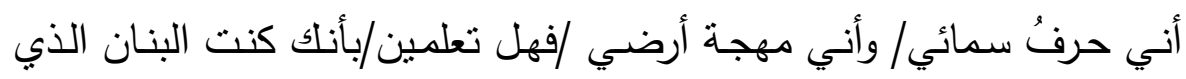

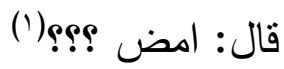
ويقول أيضًا:

وبضحكك في وجهك الثجر/يطل من الأرض نبثُّ/

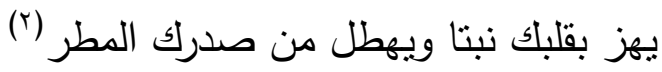
فالأرض هي السكن والمستقر منها خرجنا وإليها نعود، ثم نخرج منها تارة أخرى، قال تعالى: (منها خلقناكم وفيها نعيدكم ومنها نخرجم تارة أخرى) (r). ونرى الثاعر يفلق الأرض، ويخرج منها، وينظر حوله، ثم يُلقى تحية

الصباح، يقول أيضا: أفلق سـح الأرض/ وأخرج أنلفت حـولي/ أنظر فوقي أطلاق في الأجـواء/ صباح الخير (£)

ثم يصـور نفسـه بنبتـة لا حيـاة لها إلا بجذورها الممتدة في داخل الأرض حتى تكبر وتتمو أغصانًا وفروعا، يقول: أترك جذري ... يمتد في الأرض على استحياء /أحلم أن أكبر أن أصبح غصنًا

$$
\begin{aligned}
& \text { (1) ديوان تدور بي دوائري ص } 9 . \\
& \text { (r) السابق } 9 \text { (r) } \\
& \text { (r) سورة طه آية (r) }
\end{aligned}
$$

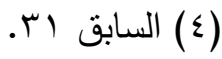


وفي قرب نهاية القصيدة يعيد ويؤكد على صورته التي رسمها لنفسها

بأنه غصن لا حياة له إلا وهو مغروس في الأرض، يقول:

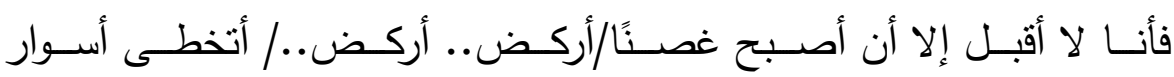

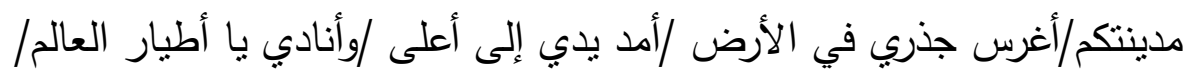

إني عش الأعشاش (')

وهو بذلك يعلن تمسكه بوطنه وأرضه، فإن كان فارقها بجسده إلا أن

جذوره مغروسة داخل وطنه وإن طالت أغصانه مدنًا وبلادًا كثيرة.

ويرى فوزي خضـر أن هنـاك قطعـة مـن الأرض مقدسـة وهي مغـايرة

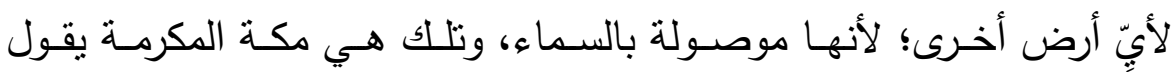

مخاطبًا لها:

يهتـز قلبـي حين تتظـرك العيـون/يسـيل منهـا توبـة نـدم؟/أم يـا تـرى فـرح

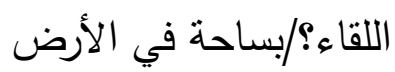

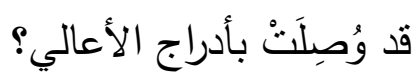

وفي نهاية القصيدة يعيد هذا الربط بين السماء والأرض، ويطلق على بلى

الأرض (الساحة البيضاء)، ويسجد في الأرض؛ ليصل إلى القرب من السماء

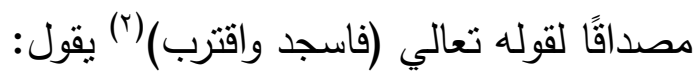

في السـاحة البيضـاء يتسـع الفضـاء / في السـاحة البيضـاء يُختََّرُ الوجود /

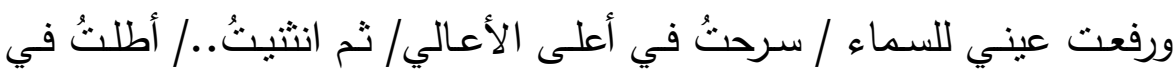

الأرض السجود/ أطلتُ في الأرض السجود (r)

ويزاوج بين معنى الأرض وهي الوطن الذي تركه مرغمًا، وهاجر منـه

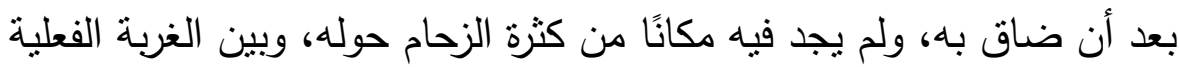

التي يحسها ويعيشها في وطنه، يقول:

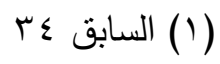

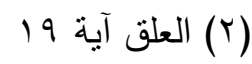

111 (Y) ديوان تدور بي دوائري 
لو حجرًا كنتُ/لأمكنتي أن أجد مكانًا/بجوار جدار/أو أُلِقى الجسد المجهد/في أحد الأركان/أبحث عن مأوى/كانت تتزاحم في الأرض بنايات/وديانٌ.. وروابٍ

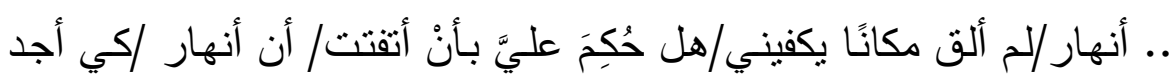

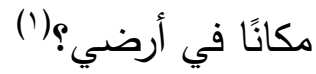

ويصور ألمسه وغربته في أرض غريبـة اضطر إليها اضطرارًا، وهي اليه تتمسك بـه ولا تريد فكاكه، وهو يحاول الفكاك والخـلاص والعودة إلى حياته الأولى ووطنه الحبيب، ويؤكد أنه مهما لاقى من غربته تكريمًا أو نعيمًا، فإنها

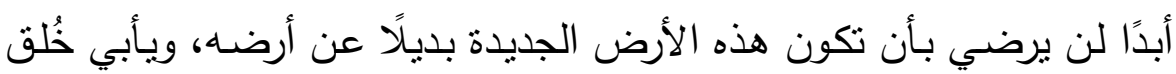

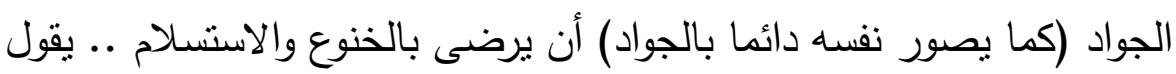
في قصيدة بعنوان (خُلق الجواد):

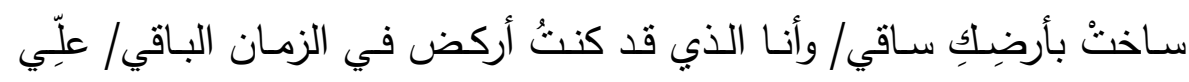

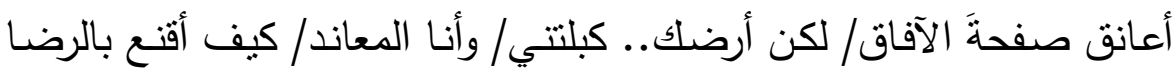

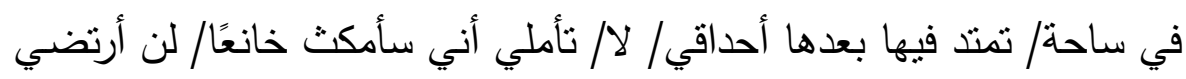

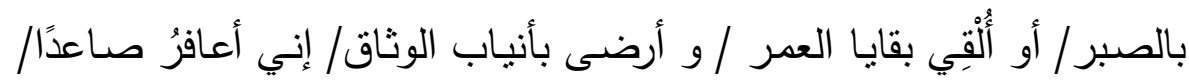

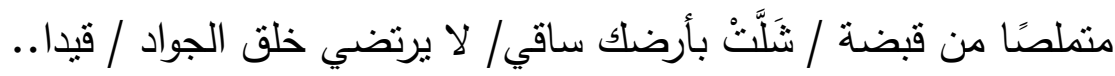
ولو كان البراح. (r)

فالقصـيدة تعبيـر عـن معاناتـهـ النفسـية بـين الأرض الغربيـة التـي تحتضـنه، والأرض البعيدة الحبيــة التي ابتعـد عنهـا ويشـتاقها ويحن إليهـا، ويصسور ذلك بصورة جواد غاصت أقدامسه في الرمل ويحاول الخروج وكلما حاول تغوص أقدامسه أكثر وتتمسك بـه الأرض أكثر، وهو يحساول ولن يفقد الأمل، فأخلاق الجواد تأبي القيد وترفض الحبس حتى لو كان في أرض براح واسعة، فهو يرفض فكرة القبد مهما كان شكلها. 
ونـراه يـزاوج بـين النيـل والأرض؛ فهمـا يشكلان المكـان بمـا فيـهـ مـن

أثنكال الحياة، فالنيل هو المـاء الذي منه كل شيء حيّ، والأرض هي الأم والرحم، وحينمـا يمتزج النيـل مـع الأرض فذللك إيذان بقدوم الخير وانتعـاش

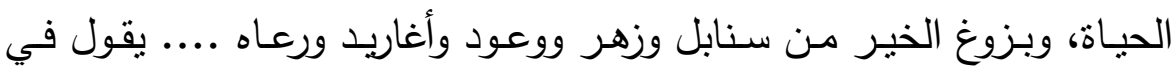
قصيدة "أنغام هادئة": الجِمالُ الخضرُ في الدربٍ إلبك/ تحمل المهر بذورًا/ فازرعيها/ تتبتُ الأرض

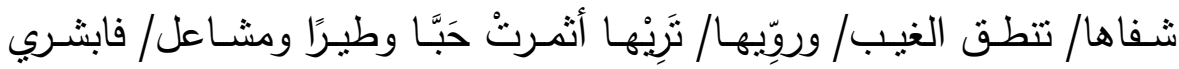
وانتظري/ فالجِمال الخضر في الدرب إليك/وخطاهـ/أنهر تجري ... وزهر ..

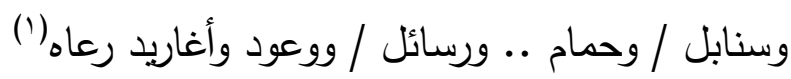
وفي قصيدة "أغنية حب" يقول: وألقي على قدميك السنابل/ أحكي عن النيل والأرض في قريتي/والعصـافير والفجر والناس والأغنيات (r). وحينما تَحْدُث الخيانـة فإن الثـاعر برى ذللك ينعكس على المكان والأرض، فالأرض تصبح خرسـاء - كما يصسورها- وهي آنذالك لا نتتج ولا تزرع ولا تثر ، فينشر الجوع والفقر وكأنه لا نيل، وكأن الأرض أصبحت بيداء مققرة .. يقول في قصيدة "مناجاة":
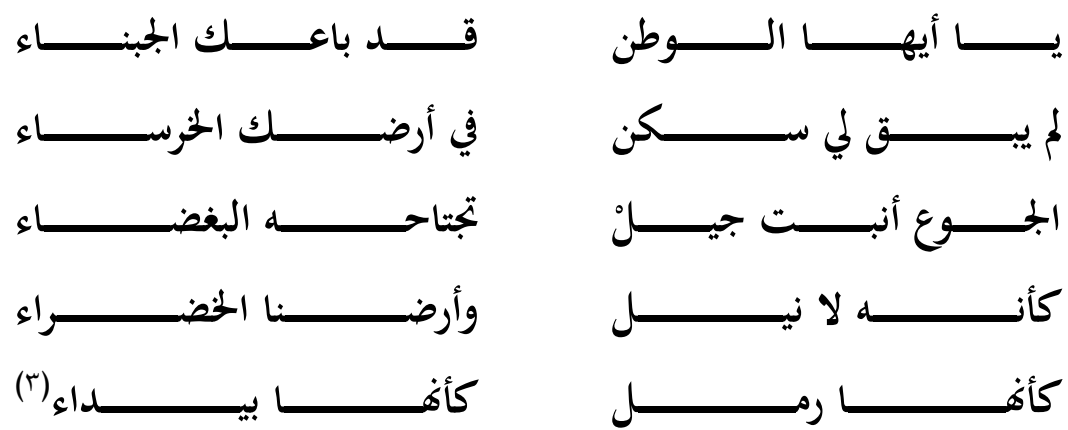


\section{حوليت كليت اللغت العربيت بإيتاي البارود (العدد الثالث والثلاثون)}

وغير ذكره لـأرض ذكر أمـاكن في الأرض طبيعيـة كثيـرة منهـا: الطريـق،

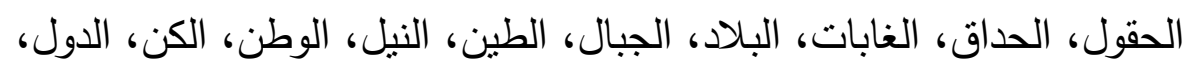

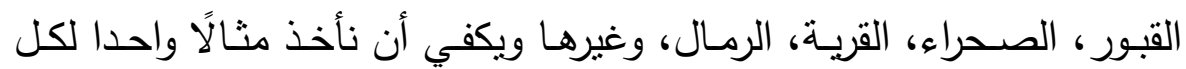
عنصر ، ونشير في الهامش إلى المواطن الأخرى في ديوانه التي ذكر فيها

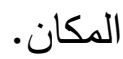

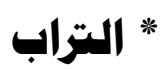

ذكر فوزي خضر التراب في أربعة مواضع|") منها قوله: أن ألف مئننة-رغم هدمي - أقوم وامضي فلا تسأليني لأينا لقد كنتُ أبغيك سنبلة/ حفنة من مياه/ وهانتذي في التراب / تراب. إنه يخاطب محبوبته التي فارقته، وفرق الموت بينهما فسكنت التراب، بل تحولت لتراب، فكل ما فوق التراب تراب، قد كان يرجو لها البقاء والحياة، ولكن غيبها التراب. وذكر التراب هنا كمكان جئنا منه وإليه نعود يقصد به المقابر ، وهناك من بسميها (التُرب) نسبة إلى التراب، قال تعالى: (منها خلقناكم وفيها نعيدكم ومنها نخرجكم تارة أخرى) (؟).

\section{* الطريتق والدرب}

ذكر فوزي خضر الطريق في ستة موضـع(ّ) من ديوانهه. ومن ذكر الطريق قوله: فمن تُرى.. / يودِّعُ المسافر؟ / والصمت والأشباح في الطريق

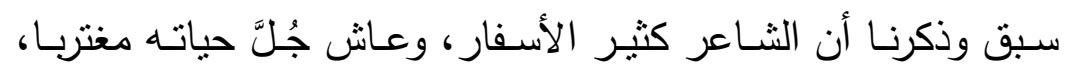
فالطريق والسفر والدروب تعرفه ويعرفها وتألفه ويألفها، فيعلم أنه بمجرد حمل ونل

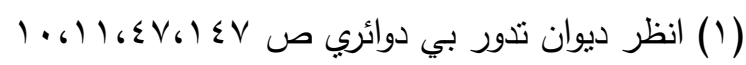

$$
\begin{aligned}
& \text { (Y) سورة طه (Y) }
\end{aligned}
$$

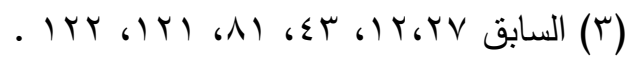


حوليت كليت اللغت العربيت بإيتاي البارود (العدد الثالث والثلاثون)

الحقيبة والسفر وحيدًا يجد الصمت والخيالات والأشباح تطارده طوال الطريق، وكل من سافر يستذكر في طريقه الأهل والأحبة، ويخاف مما هو قادم.

\section{* الحقول *}

جاء ذكر الحقول في الديوان مرتين، منها قوله:

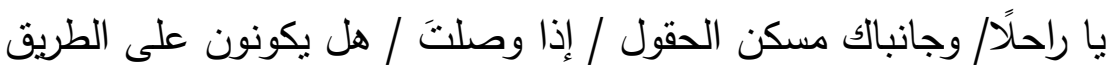
في انتظار وجهلك القديم؟

فالحديث لا يزال عن السفر ، نراه يذكر عدة أماكن في هذا المقطع منها (مسكن الحقول)، وهذا مكان ميتافيزيقي متخيل، والحقول مكان، والطريق

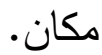

والمعنى: يخاطب الثـاعر نفسـه - فهو الراحل دائيًا - بأنـه الراحل وفي جانبيه الحقول، فهو يحمل الوطن والحقول بداخله، كما يحمل الثخوص والذكريات، ويتسـاءل: هـل حينمـا يعـود بعـ زمـن طويـل سيجد مـن تـركهم ينتظرونه على الطريق؟ ويرونه ذاك الثخص الذي سافر منذ زمن بعيد، ولم تغير فيه الأيام شينًا فهو بصورته ونفسه القديمة.

\section{الهدائق *}

جاء ذكر الحدائق في الديوان عدة مرات، منها قوله: تبتسمين لوجه المساحيق / ثم إذا ما دخلت الحدائق / لا تجدين بها اللوحات /

ويضحك في وجهك الثجر (') وله أيضًا قوله:

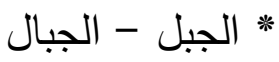

جاء ذكر الجبل والجبال قرابة العشر مرات (r) 
ولعل أول قصيدة في الديوان بعنوان (ألوان) هي ترجمة لفلسفة الثاعر عن بداية الكون وبدأ الخليقة، فهو يرى كل ما في الحياة قد بدأ بجبل ينهار فيتكون منه بقية المخلوقات، وهو أيضًا دلالة على شموخ الثاعر واعتزازه بنفسه، وتلك يلك حقيقة لمستها بنفسي؛ فالثاعر عظيم الاعتزاز بنفسـه فهو جبل شامخ، وجواد جامح، ... يقول: جبل ينهار / كانت تتماسك فيه الأحجـار / والآن تقلت أيد من أيد / حين تفجر بركان في قدميه/ بطلق أنهارًا حمرا جبل يركض / تتناثز منه الأحجار / تقفز منه كي تتقذ أنفسها / تتدحرج في دنيا شاسعة /حجرًا حجرًا
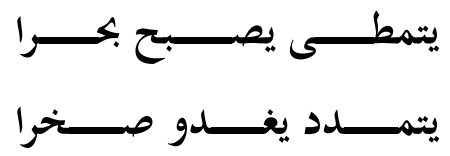

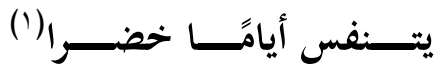
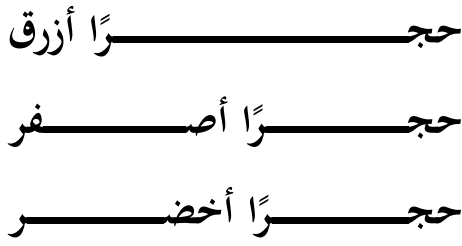

وفي قصيدة بعنوان (مكة) بدأها بذكر جبال مكة الثماء، فقال: بين الجبال الثم ترتاحين صابحة / بأطراف النهار وفي الليالي / كيف العتيق يظل دومًا طازجا؟/ يهتز قلبي حين تتظرك العيون / يسيل منها توبـة ندم؟/ أم

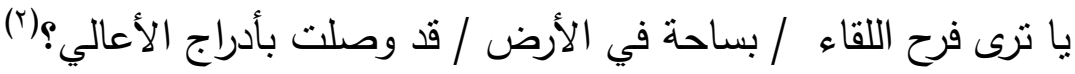

\section{| الصمراء *}

استخدم فوزي خضر الصحراء في مواطن كثيرة من ديوانه، فاستخدم الصحراء والصحارى والبيداء، وسبق وذكرنا أن الثاعر عاش سنوات طويلة فئة من حياته في المملكة العربية السعودية، وقبلها عاش في ليبيا، وهاتان الدولتان تتميزان بطبيعتهما الصحراوية، فمن ذلك قوله:

$$
\begin{aligned}
& \text { (1) ديوان تدور بي دوائري ص 7، } \\
& \text { (r) السابق } 9 \text { (r) }
\end{aligned}
$$


حوليتة كليت اللغت العربيت بإيتاي البارود (العدد الثالث والثلاثون)

حجر أزرق /............." (1) وقوله:

رحلت في الصـحراء دونمـا عيون /مقطَّع اليدين /أحمل في - في جيبي -

جفوني الممزقة(r)

وقوله:

وأرضنا الخضراء /كأنها رمل، كأنها بيداء(r)

وقوله:

تُجمِّعنا الحرب: قبضـه/نشق الصحاري /تطير بنا العربات /ومن حولنا - في الرمال - تطير الجبال /يطير السحاب، يطير الضياء، يطير الدجى /ونشق

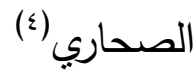

: تشق الصحاري ../لكي يصحو الطفل من نومه باسمًا تُشق الصحارى ....

* القبر - والقبور

يذكر القبر حين برثي أبـاه في قصبدة بعنوان: (البحث عن مواضـع الأقدام) عدة مرات، منها قوله في ختامها: يا قبر أبي / في صدري أنت / وما بنبض في شرياني ليس نماء/ لكن أعشابًا بربه

تتبت حول القبر (o)

* القمبة *

القريـة هي ملاعب الصـبا للثـاعر، وهي في خيالـه وذاكرته، وحين يذكرها ينسبها إلى نفسه حبًا وانتماء، يقول:

$$
\begin{aligned}
& \text { (1) السابق ص } 7 \\
& 99 \text { (Y) السابق } \\
& \text { va (r) السابق }
\end{aligned}
$$

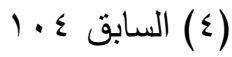

$$
\begin{aligned}
& 9 \text { (0) السابق الو } 9
\end{aligned}
$$


حوليتة كليت اللغت العربيت بإيتاي البارود (العدد الثالث والثلاثون)

وألقي على قدميك السنابل/ أحكي عن النيل والأرض في قريتي /والعصافير و

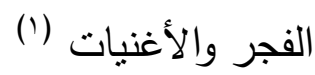

كـا يـذكر الغابـات، وبـلاد الطـين، والرمـال، وغيرهـا مـن الأمـاكن الأرضـية الطبيعية التي لها في نفسه أثر وفي شعره مكان. (r) المكان الواقعي الأرضي العامر الصناعي: المكان الصناعي: هو المكان الذي يتدخل الإنسان في صنعه وإنشائه، مثل: المـدن والقصـور والقـلاع، والمسـاجد والمـآذن والقبـاب، والثــوارع والبسـاتين والحقول.

ولهـذا المكـان وجـود متميـز عنــــــوزي خضــر، فــراه يـذكر المــن

والثـوارع والـدور والبيـوت والفنـادق والقصـور والمـارس والرصيف وواجهات المحال والحجرات وغيرها، وكأنه يمتزج بها امتزاجًا حين يكون المكان محبيًا

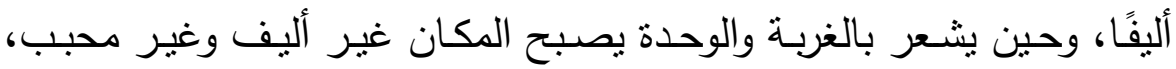

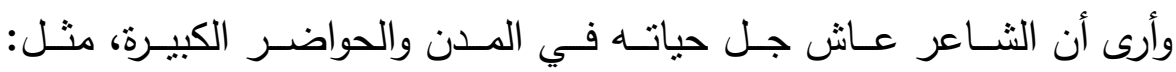
الإسكندرية والقاهرة في مصر ، والطائف بالسعودية؛ فهو محب للمدينة عاشق

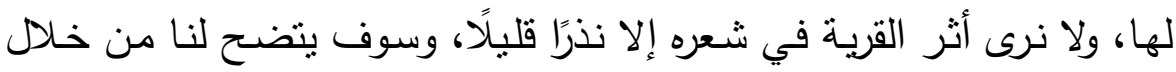
التحليل مدى نآلفه مع المكان من عدمه.

\section{: المنأد}

يأتي ذكر المدينة تحت مسمى (المدن المستبدة) حينما يستشعر أنـه غريب في بلاد بعيدة، وربما هاجمه الموت وحيدًا غريبًا بلا أهل أو ولد، فيأتي

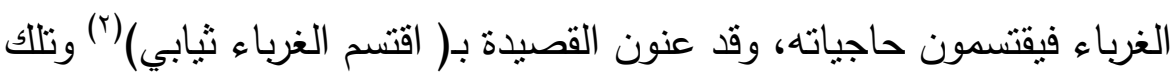
وتلك المدن المستبدة لا تعرف الرحمة بالغرباء، ألفة بينه وبينها ... يقول: وققت غريبًا/ وفاجأني الصمت في لحظة الحكم/ فاقتسم الغرباء ثيابي ... 
ويضحك خوفي فالصيف كان يفرقنا راميا بي - لأرصفة المدن المستبدة. ويعود ليذكر رصيف المدن القاسية المستبدة في ذات القصيدة مـرة

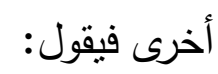
يجوع بأرصفة المدن الغرباء بأمعائهم لغة غاضبة. فكما نرى؛ فالمكان بلا ألفة أو محبة فهو غريب وحيد والمدن المستبدة - كما يرى - لا ترحم الغرباء، ولكن حين يعود إلى وطنه وأهله تكون المدينة محببة ونه

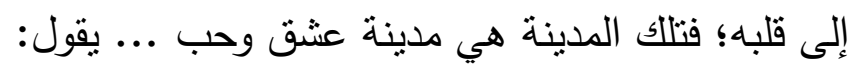

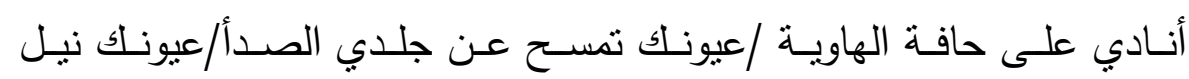
يفيض/ويجتاح في ركضه الظمأ/مدينة عشق تراودني في الصباح نوافذها (1) وفي قصـيدة (اقتسـم الغربـاء ثيـابي) يطلـق على المـدن جمعـا آخـر، وهـو (المدائن)، فيقول: فيضحك قلبي منتشيًا بالمدائن. وفي قصيدته (العيد منسي)(؟) يصاحب المدينة، ويرافقها، ويسير مع شوارعها، بأن وتحادثة أرصفة الشوارع وواجهات المحال. - وقد يستخدم المدن المجازية، كقوله: فعلّمنا السير إلى مدن الحرف

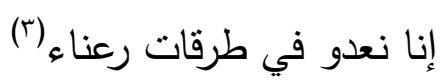
وفي القصيدة ذاتها يذكر المدن والمدينة مرة أخرى. وله أيضًا في استخدام المدن مجازا قوله:

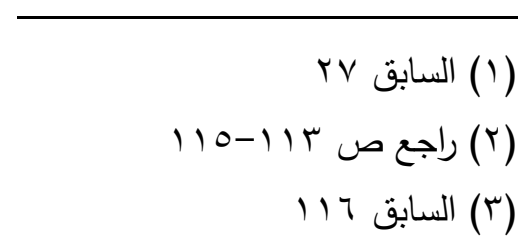


حوليتة كليت اللغت العربيت بإيتاي البارود (العدد الثالث والثلاثون)

وجهـه لغـةُّ/ تستبيح بكارة كل الحـروف الوليدة/ وجهـه مدن/ فـاعرفوا المـدن

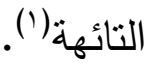

كما يذكر مدنًا بأسمائها، مثل: مكة والمدينة والقدس، ويعنون قصيدة

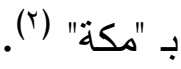

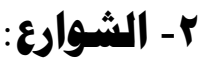

هي المتنفس للناس حين تزكمه حوائط الدور، وتضيق بهم جدران

المنازل، فيخرجون إلى الثـوارع وفسـتها، وتتطلق معهم آمـالهم، فمنهم من يذهب للعمل وطلب الرزق، ومنهح من يخرج لفسحة الثارع منطلقًا نحو مآرب

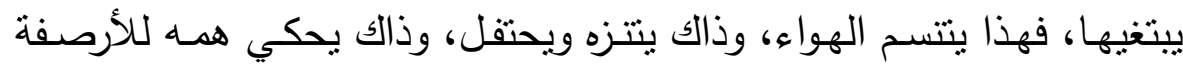

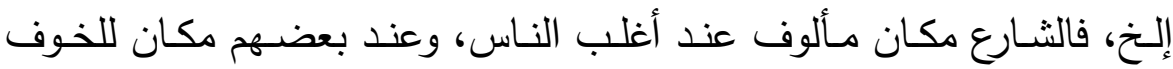
والرعب، والأمن بالنسبة للأخير يكون في البيت.

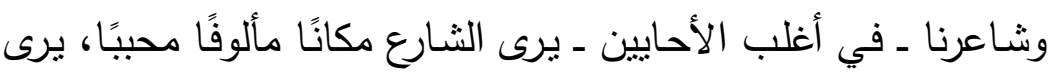
فيهـ الحريـة والانطـلاق والمتعـة، فهو يلفها حول خصـره، ويرقص بها رقصـة

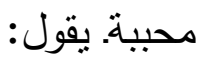
حينًا....

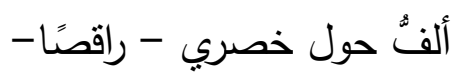
شوارع المدينه أرى الدكاكين تتاثرت بضاعة ومشترين أرى مليكها البدين معلقا من رجليه في طرف الحزام تفاجئني الضحكات (r) 
حوليتّكليت اللغت العربيت بإيتاي البارود (العدد الثالث والثلاثون)

وقد نوقظه ضحكة لأحد المارة في الشوارع، وهو نائم في أسرة أحد

الفنادق، فيقوم ليرقب السماء ونجومها، ويتذكر أحبته .. يقول:

فوق أسـرة هذي الفنادق/ توقظني ضحكة في الثـوارع / في ليلة تتورم فيها

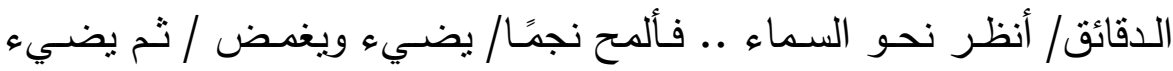

وبغدض (')

ويؤكد شاعرنا أنه يرى الثنارع مكانًا أليفًا محببًا، حتى أنه يصور نفسه

جزءًا من هذا الثـارع، وكأنه ينبت في الثـارع كالنباتات، فيقف ثابتا شـامخا يرقب كل المشاهد .. يقول:

فجأة تجدين الذي غاب / بضحك بين بديك مساءًا نابتًا في الثوارع / بنظر

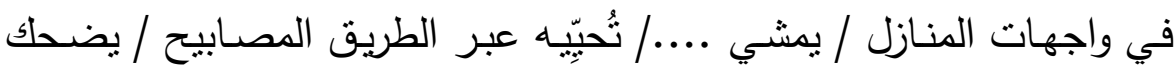

في واجهات المحلات ونات المنارن

فربما عاد فجأة بعد غياب طويل، ووقف بين يدي حبيبته ضـاحكا

سعيدًا، وكأنما نبت في شوارع المدينة، يعرف كل شيء فيها، وتجمعه الألفة بكل مكونات الثشارع؛ من محال ولافتات ومصابيح.

وكما صور نفسـه نبانًا في النموذج السابق عاد وصور نفسه غصنًا

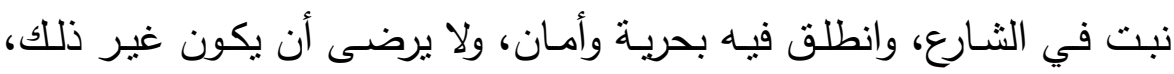
يقول:

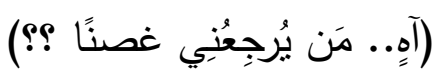

أخلـع ثوبي../ أجري في الثـارع عريانًا/ اتخذوني أنتم خشبًا في مدفأة/ أو أو

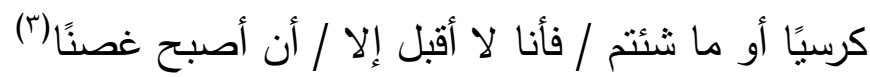


ويكرر تلك الصورة التي تخلع فيها الأشياء ثثابها وستوره، وتتجرد من الحجب، وتتطلق بـلا قيود أو حواجز، فكمـا خلع الغصن ثيابه، كذللك تخلع الكتب ثنابها، وتخرج راكضة في الثوارع ... يقول: تهُبُُّ مِن الرفِّ كُتبي/ وتخرج راكضة في الثوارع/ تخلع عنها الثياب/ تولول/ تلطم وجها / وتهيل التراب على رأسها/ تتكوم فوق الرصيف (')

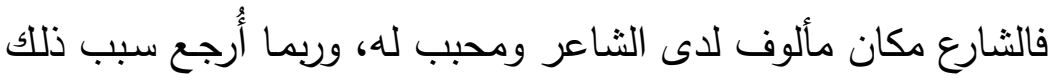

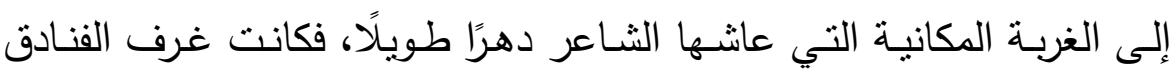
بمثابة السجن والوحدة، ويرى في الثارع الحرية والانطلاق والأمن من الوحدة، كذلك حين يعود إلى وطنه في الإجازة يسير في شوارع مدينته مستمتعًا بألفة

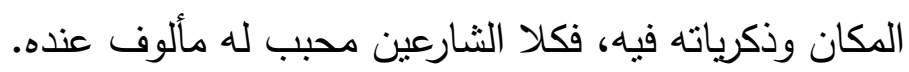

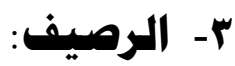

جاء ذكر الرصيف عدة مـرات عند فوزي خضـر، وقد ارتبط ذكر الرصيف مع المفهوم السائد لدى الناس بارتباط الرصيف بالمشردين والغرباء،

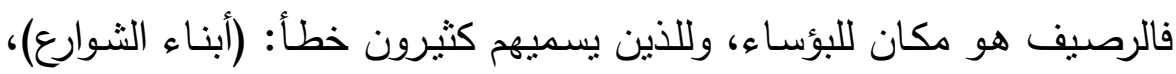
والذين لا يملكون سقفًا يستظلون بهه، وكذلك هو مكان للغرباء الذين انقطعت بهم السبل، وليس لهم مأوى .... يقول:

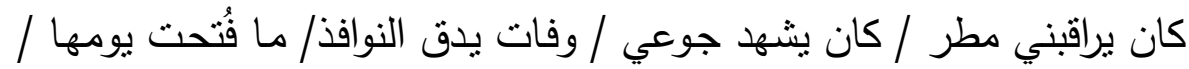
قال: فوق الرصيف غريب / فما سمعته القلوب / وجاء يراقبني اليوم/ جاء

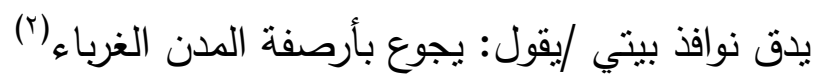

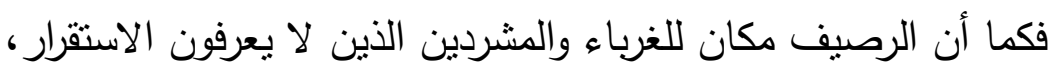
كذلك هو مكان للباعة الجائلين الذين لا يعرفون الاستقرار ، فليس لديهر مكان 
ثابت؛ لذا فهم يبيعون البضائع خفيفة الوزن رخيصة السعر ، وليس لديهم مـع مذان هذا المكان ألفة ولا مودة ... يقول:

تهيـل التـراب على رأسـها / تتكوم فـوق الرصـيف / تبيـع المشـدات والـروج للعابرات / تبيع طلاء الاظافر والأحزمة / أقول لها: كيف أصبحت بائعة في الرماف

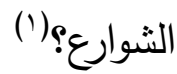

\section{ع - الديار والبيوت والفنادق والقصور:}

يستخدم فوزي خضر هذه الأماكن الحضارية الصناعية في شعره وهو

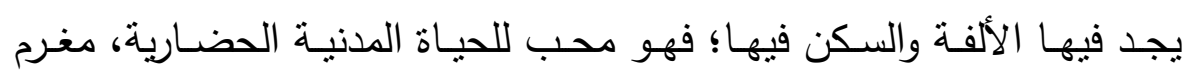
بالمدن الكبيرة وما فيها من أسباب الحياة والتقدم . نراه يطلب إلى محبوبته أن نكون له الرحمة والمطر والدار والسكن ... يقول: وكوني رحمة الأمطار / تأني فجأة في موسم النار / وكوني - ليلة- داري/ فإنَّ

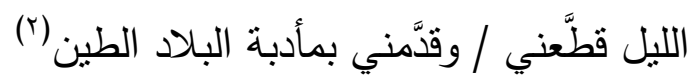

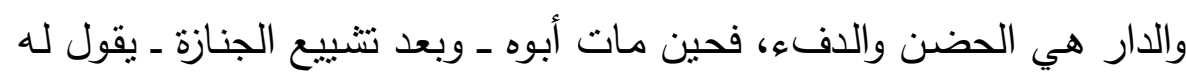

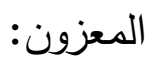
(مراسم موت أبيك انتهت

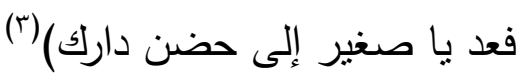
ويذكر (البيوت) الفخمـة التي يدخلها ويجلس فيها، وهي دلالتة على التقدم والرفاهية، ففيها أجهزة التكييف التي تفعل بالهواء ما يفعله النسيم العليل في صيف حار، وكذلك بها من الأطعمة ما لذ وطاب ... يقول: 
حوليتة كليت اللغت العربيت بإيتاي البارود (العدد الثالث والثلاثون)

أدخل في البيوت / أجلس في قاعاتها المكيَّفه/ يعرض نفسه الطعام كي أعيث

فيه (')

ومن البيوت من لها خصيصـة دون غيرها، فليست بيوت مكة ككل

البيوت، فالقادم إلى مكة حين يستشرف منازلها وبيوتها من بعيد يحس بفرحة تغمره، وسكينة تملؤه، وقدسية تكسوه.

وليس كل بيوت مكة سواء؛ فبيت الله الحرام غير كل بيوت الله على

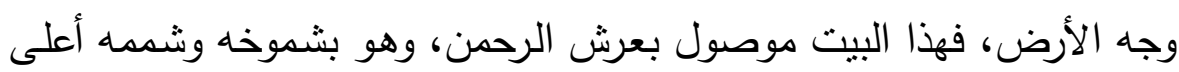
من كل الجبال الثُّم، فلهذا المكان ما ليس لغيره من الرفعة والثموخ والقدسية ... يقول:

يهنزّ قلبي / حين تبدو للعيون بيوت مكة/ ها هنا درج العوالي / يهتز قلبي /

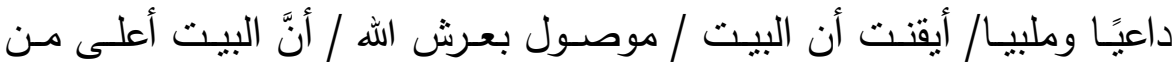

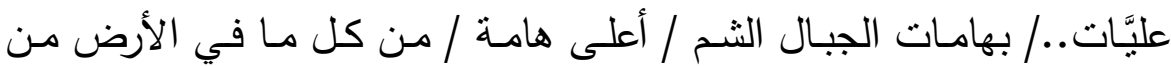

(๖) عالي

كما يذكر أماكن أخرى، مثل: واجهات المحلات والدكاكين والبيوت،

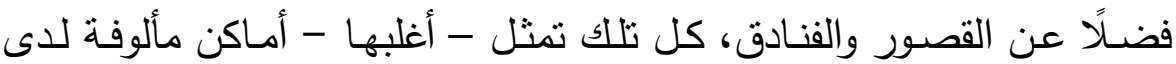
الثاعر ، وكلها من الأماكن الأرضية الواقعية الصناعية العامة.

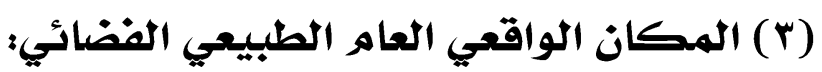
الستماء:

هي المكان الأرحب في الكون، فمتى ضاقت بالإنسان أسباب الأرض

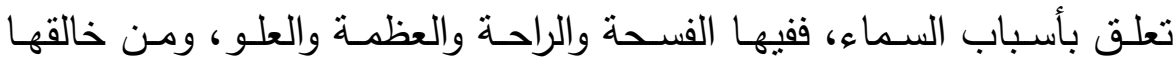
نستمد العون وإليه يرفع الدعاء.

\footnotetext{
(1) السابق سז

(r) السابق (1)
} 


\section{حوليت كليت اللغت العربيت بإيتاي البارود (العدد الثالث والثلاثون)}

وشـاعرنا شديد الاعتزاز بالنفس، يرى في نفسهـ أنه يشبه السماء في

عطائها، وفي معرفة البشر، ولديه الخبرة التي تمكنه من معرفتهم ... يقول:

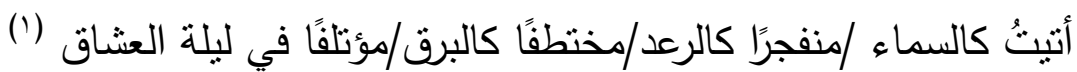
وقد يأتي ليس كالسماء، وإنما وهو يحمل السماء في يديه؛ دلالة على لئ ما يحمله من خير وسعادة ... يقول:

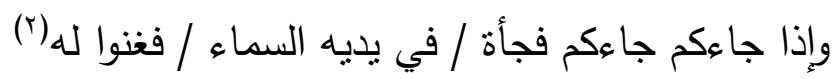
وفي قصيدته (الرحلة في مدن الأسماء) - وهي من قصائد مدح النبي

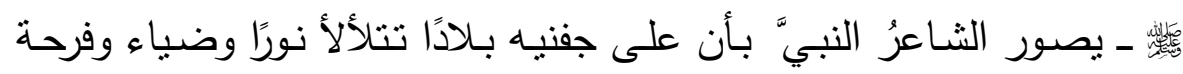

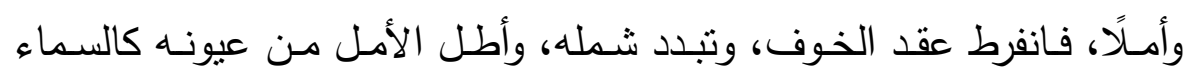
الصافية الواسعة، ورسم السعادة بابتسامة رائقة، وربَّتَّ على أكتافنا ومضى ... يقول الثاعر : وأتيتَّ وعلى جفنيكَ بـلادٌ تتنألأ/ وانفرط الخوف / أطلت من عينيك سماء/

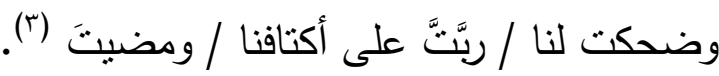
وفي قصيدته المعنونـة (السماء.. خاتمًا من الألماس) ينظر الثـاعر إلى السماء على أنها مقياس للراحة أو الضيق، فكلما كان الإنسان في حالة

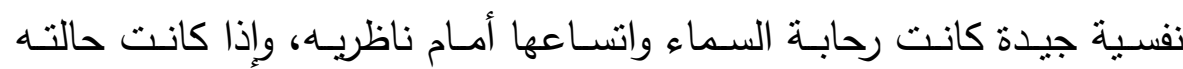
النفسية سيئة كانت السماء أضيق من خاتم في إصبعه ... يقول:

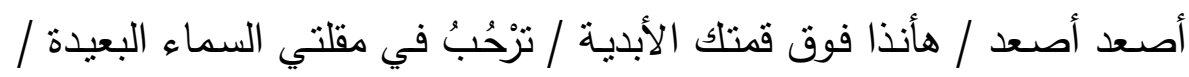
أزعق وحدي تدفعني الريح (.....

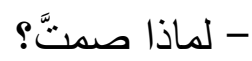
- أنا: شجَّت اللحظة المستبدة رأسي

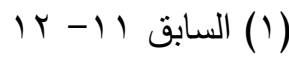

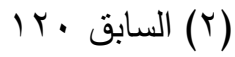

$$
\begin{aligned}
& \text { IV V السابق (r) }
\end{aligned}
$$


حوليت كليت اللغت العربيت بإيتاي البارود (العدد الثالث والثلاثون)

- تضيق السماء / فتصبح خاتم ماس / يضيق على رقبتي / وأفتحها فتضيق

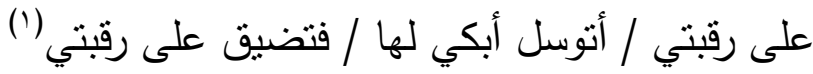
وساعة الفرح تطل السماء راقصة في العيون الضاحكة .... يقول: وتفقس عبرخطاه البراعم تضحك في مقلتيه السماء( (r) وحين الحزن تتشق السماء، وتبدو مظلمة بلا ضياء ...يقول راثنًا: قُتُلتُ يا صديق في بداية الطريق شققتُ جبهة السماء في تشاقطي

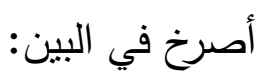

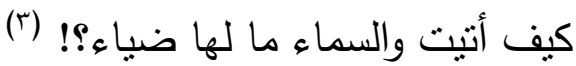

وساعات أخرى للحزن، الطريق فيها بكاء، والسماء غير السماء... يقول: كان الطريـق بكاء ...وكان / بائعا بالسماء سماء ...وكان / سامقًا كالرياح

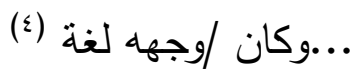

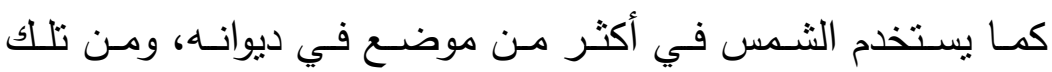
المواضـع حين يصـور نفسـه كنورس مستبد قوي يسـافر إلى سـاحل الثـمس، فينزع منها الحريق ويقذفه في البحار فتغلي ... يقول: وأرحل كالنورس المستبد إلى ساحل الثمس أنزع منها الحريق، وأقذفه في البحار فتغلي (o) 
حوليتّكليت اللغت العربيت بإيتاي البارود (العدد الثالث والثلاثون)

كما يصور نفسـه فارسًا، ويصور الثمس حصـانًا، وهو يمتطي صـوته وفي

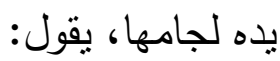
فها أنا أتيثنُ

في يدي لجام الشمس والرياح (') وتردِ الشمس في دوائر الثـاعر بعدة صور - غير ما ذكرنا آنفًا -

من ذلك حين يجعل دائرة العودة لمحبوبته نورا يكثف كل ظلام، ويصبح سبيًا في خروج شمس الصباح فرحة سعيدة تقبل أجفان المحبين .... يقول: غدًا سآتيك نورًا، جوابًا لكل سؤال

لتخرج شمس الصباح تقبل أجفاننا (r) وكذلك الدائرة المقابلة هي دائرة السفر والابتعاد، وتلك الدائرة تجعل جل جلك الوجوه شاحبة، ويمضي يجرجر ضلوعه، ويرفع جمجمته بيديه كلما هوت منه إلى الأرض، ولا يخفى أن تلك الصورة الباكية الحزينة دلالة على حزنه الكبير

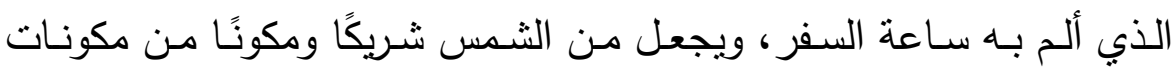

$$
\text { الصورة ... يقول: }
$$

وهأنذا قد مضيتُّ/ أجرجر خلفي ضلوعي / وأرفع جمجمتي بيدي / فتهوي

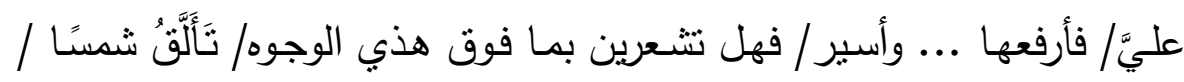

وتحمل نفسًا/ بها من تجاعيد هذي السنين سمات (r) كما يجمع بين عدد من الظواهر الطبيعية الفضائية في مكان واحد، وذلك في

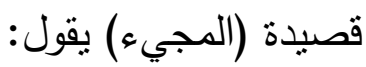
أنتيت كالسماء منفجرًا كالرعد

$$
\begin{aligned}
& \text { (1) السابق } \\
& \text { VV السابق } \\
& \text { (r) السابق 9س }
\end{aligned}
$$


حوليتة كليت اللغت العربيت بإيتاي البارود (العدد الثالث والثلاثون)

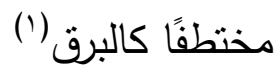

وحين يذكر مكة المكرمسة يـى أنها قد وُصِلتنْ أرضـها بالسـماء في

إثـارة إلى مكانتها المقدسة في قلوب المسلمين، وما لها من خصوصية عن بقية البلاد؛ فهي مكان الألفة والطمأنينة والسكينة، فيها يرفع الدعاء وتستقبل بركات السماء ....يقول: بهنز قلبي حين تتظرك العيون يسيل منها توبة؛ ندم؟ أم با ترى فرح اللقاء بساحة في الأرض ترض

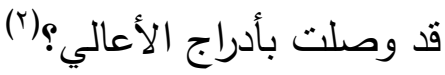
وتتزاحم الفضائيات في قصيدة (البحث عن ينابيع النور) ما بين نجوم وأقمار وليل ساهر وسحاب مظلم ومطر وغيرها ... يقول: أعود بـا بـاب السنين / على جفوني حفنة مسن النجوم تأتلق/ وفي ضـلوعي تتحني الطرق / وفي عيوني ألف ليل ساهر / بسأل عنكا/ تهمهم الأقمار في دمي / ويهبط السحاب في عيوني مظلمًا/ يمطر شوكًا/ وأنت لم تزل مقطبا/ ألا تعبد لي إشراقتي في يومي الموعود؟(r) وهكذا يتمتع شاعرنا بروعة في مشاركة المكان لله في أفراحه وأتراحه، ومشاعره ونبضاته، في صورة كلية تجمع في أطرها تتاغم الإنسان مع محيطة وتفاعله مع عالمه. 


\section{ثانيا: المكان الهخصص:}

وهو المكان المحدد، مثنل: وادي النيل، وجبل عرفات، وصحراء النفود، والخليج العربي، ومثل شمس أغسطس، وقمر النصف من شعبان، والنجم سهيل، وريح الصبا.. وما شابه ذلك. وتلك الأماكن كثيرة في الديوان، وهي قريبة لمن ينشدها؛ ولذا سآخذ نماذج قليلـة لها تبين الغرض وتوضـح المقصد، مـن ذلك مـا ذكره مـن أمـاكن مخصصـة في قصيدة (مكـة)، مثل : عرش الـرحمن، السـاحة البيضـاء، الجبال الثم، أرض بها سار الرسول، بيوت مكة، وغيرها، يقول: حين تبدو للعيون بيوت مكه / هنا درج العوالي هتز قلبي داعيًا وملبيا أيقتت أن البيت موصول بعرش الله أن البيت أعلى من عليَّات بهامات الجبال الثم أعلى هامة من كل - ما في الأرض - عالي ماني في الساحة البيضاء بشرني فؤادي بالحصاد وبالقطاف وريت كيف الطير حول البيت طاف وأتت فراشات لطاف فتزاحمت وتقاربت وتباعدت أرواح من تلاك التي جاءت فراثات تطوف على رؤوس الناس

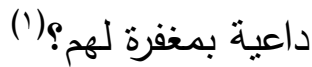

ويشير الثـاعر إلى سماء بعينها تلك (السماء الذهبية و العيون الأبديـة)،

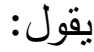


حوليتّا كليت اللغت العربيت بإيتاي البارود (العدد الثالث والثلاثون)

$$
\begin{aligned}
& \text { كيف يبدو عندكم خدُّ السماء الذهبية؟ } \\
& \text { كيف تبدو في ردائك } \\
& \text { والعيون الأبدية } \\
& \text { كيف تبدو والأرائك؟(1) }
\end{aligned}
$$

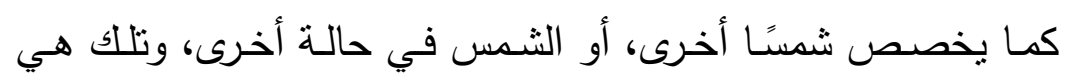
شمس الصباح، حين تقبل الأجفان وتوقظ النيام .. يقول:

غدًا سآتيك نورا، جوابًا لكل سؤال / لتخرج شمس الصباح تقبل أجفاننا (؟) والديوان به كثير من هذه الأماكن المخصصة، والتي لها في نفس الثاعر أثر لثرال خاص أو مكانة خاصة عن غيرها من الأماكن.

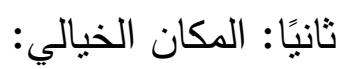

هو مكان يبتدعه خيال الثـاعر ، يضم تجربـة عاطفيـة وفكريـة تجري في عالم غير عالم الواقع، عالم خيالي بحوادث خيالية، لكنها تحدث في مكان محد، يختاره الثـاعر من مخزون معايثته للأمكنة، وهي أماكن مجازية من

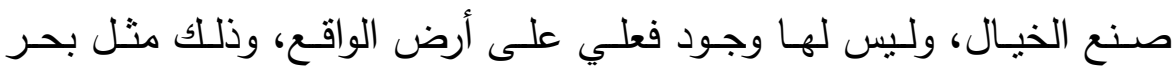
الضجر، مواسم العشق، المدائن الجسدية، بحر الدماء، مملكة الموت، بطون الحقول ...الخ

وتلك الأماكن هي الأكثر إبداعًا وتميزا لدى الثـاعر ، فهو لا يجد في الواقع ما يوضـح فكرته ويعبر عن مراده، فيلجأ إلى المكان الخيالي المختلق الذي ينقل بـه المتلقي إلى عالمهه الذي ينشده، وذلك مثل قول شـاعرنا: (وها أنت في الصمت)(")؛ جعل الصمت مكانًا تسكن بـه محبوبته، وكأنه جدران عازلة أو قيود مكبلة، فهي داخل صمتها محبوسة وفي أغلالة موثقة. وفي القصيدة ذاتها يقول: 


\section{حوليتة كليت اللغت العربيت بإيتاي البارود (العدد الثالث والثلاثون)}

إذا زار لحملك صـوتي /وطوَّف عبر مدائن جسـك /وارتعشـت تحت خطو الحروف العروق/فضمي الجفون على دمعتين /............. يهد جدار العذاب /وخلف الجدار جدر/فضمي يديك على صرخة |أطلقتها سدوم بعينيك حين أتيث(') وكذلك يجعل من الأماني والدموع أماكن يرحل بينها، يقول: ها أنا أرحل بين الأماني والدموع

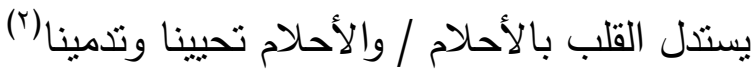
ويصور جسم محبوبته بمدائن جسدية يتمتع بالتتزه فيها يروح فيها ويجيء:

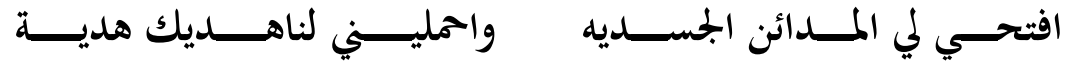

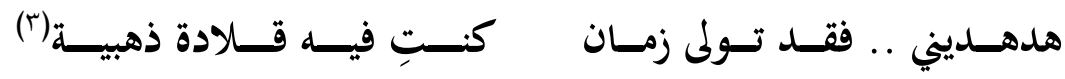
ويصـور بجميـل خيالـة مدينـة لا شـيء فيها سـوى الحب والعشـق، ويسـيها (مدينـة العشـق) تغازلـه نوافذها في الصباح، وتسـامره مصسابيحها في المسـاء : ميقول:...

عيونك تمسح عن جلدي الصدأ عيونك نيل يفيض /ويجتاح في ركضه الظمأ مدينة عشق ../ تغازلني في الصباح نوافذها وتسامرني في المساء مصابيحها وتقاسمني حجرتي الخالية(£) كما يصور وقوفه بين يدي محبوبته بوقوف ناسك في معبد منكسًا رأسه، طالبًا العفو والقرب، فيجعل المكان الذي تقف فيه معبدًا للنساك والعبَّاد ...يقول: 
حوليتّكليت اللغت العربيت بإيتاي البارود (العدد الثالث والثلاثون)

مسربلًا بالليل جئتُ / واقفا وحدي /منكسًَّا أمام معبدك /ألثم السماء في يديك /

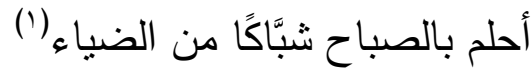

وفي القصيدة ذاتها يجعل محبتها دارًا، يقول: وتركت القلب عريانا خجولا في ديارك.

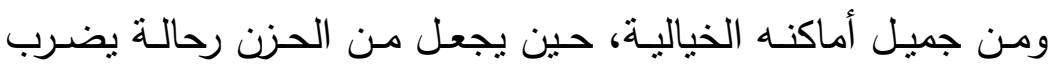

خيامه حول جفونه، وما ذللك إلا من فرط الحزن الذي ظهرت آثاره على عينيه

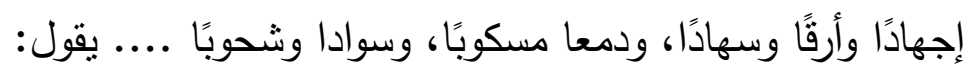

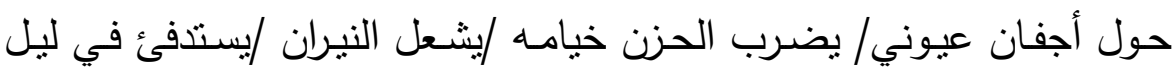

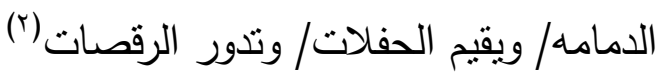

وفي قصيدته (أعرف الآن مواعيد الغرق) يصور أمساكن خياليـة كثيرة، منها:

(فكي السفر، ناصية السهر، مقاعد السمر ، بوابة الصمت)، يقول: أسقط بين فَكَّي السَّفَرِ / يعصران قلبي / ويدهسان وجهي /فكيف آتيك بقلبي / وبوجهي الآن يا سائلتي ؟/ كلاهما يثـهق في دمائي /ينتظر ابتسمة العيون

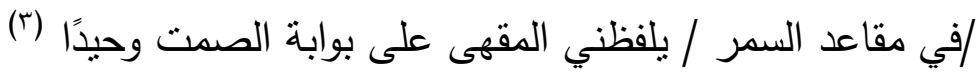
ويصور قلبه النشوان سباحًا يسبح في بحر من الصخور والأحجار، فيقول:

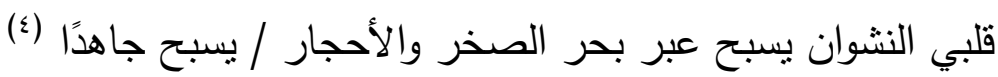

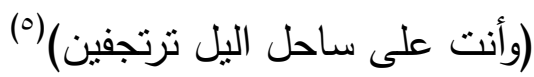
فضلًا عن أماكن أخرى كثيرة في ديوانه، منها: (جدار الزمان /قصور

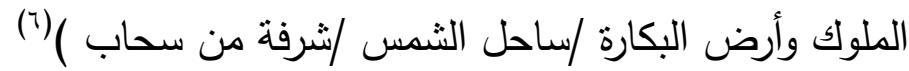


حوليتة كليت اللغت العربيت بإيتاي البارود (العدد الثالث والثلاثون)

و (مملكة الموت(')،حقول المساء صب7 • (،بطون الحقول V • (1، مدن الحرف

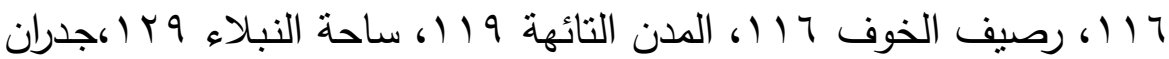

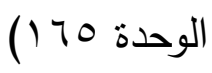

فالثـاعر يبتكر مكانًا خياليًا إذا لـم يجد في الواقع مكانًا يعبر عن

فكرتـهـ ويبـرز مـراده، وهكذا يكـون الثـعر عالمًا فريـًا بـديعًا يصـنعه خيـال

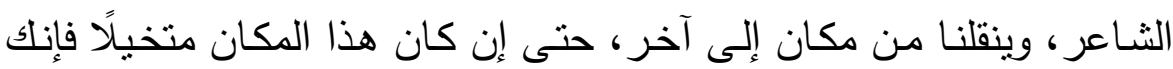
تسنطيع أن تذهب إليه بخيالك، وتطوف مـع الثـاعر في عوالمـه الخاصـة، وأماكنه المخترعة. 


\title{
المبحث الثالث
}

\section{دلالات الاكان في شهر فوزي خضر}

\author{
أ- دلانت نفنسيت

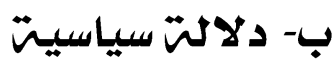

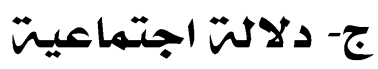

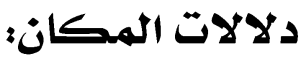 \\ الدلالت لغتّ:
}

الدلالة في اللغة من قولهم: (دللْتُ بهذا الطريق: عرفته، ودللتُ به أدل

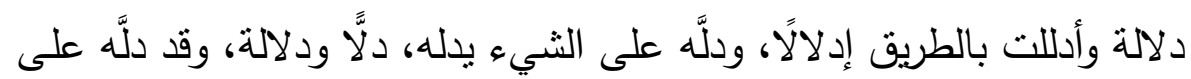

الطريق يدله دلالة ودِلالة ودُلولة،والفتح أعلى)|' (').

الدلالتّ في الاصطلاح:

هي كون الثيء بحالة يلزم من العلم بـه العلم بثـيء آخر، والثيء

الأول هو الدال، والثاني هو المدلول (r).

وسـنتتاول ـ في هـا الفصـل ـ دلالات المكـان النفسية والسياسـية

والاجتماعيـة، وقـد تكونـت هـذه الــلالات مـن مجموعـة المشـاعر منتـابهة

ومتقاربة كونت دائرة تعبر عن الدلالة في إطلار استخدام المكان الدال على ولى

هذه المشاعر، وبالتالي الدلالة النفسية التي يرمز إليها.

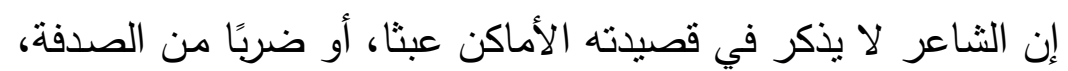

وإنما لكل مكان مذكور في القصيدة غاية وهدف، ودلالة تكمن خلفه، والمنلقي

منوط به البحث والتتقيب وراء تلاك الأماكن واكتشاف ما خلفها من الدالالات.

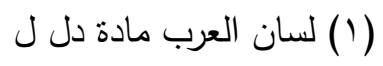

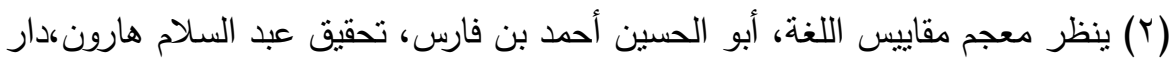

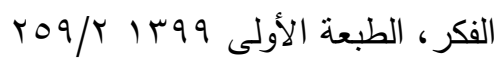


حوليتة كليت اللغت العربيت بإيتاي البارود (العدد الثالث والثلاثون)

وتتتوع الدلالات حسب ما يتراءى للمبدع، فقد تكون الدلالة نفسية أو

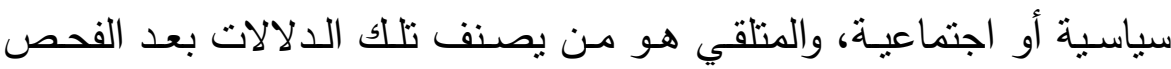
والتمحيص.

وشاعرنا يرمي من خلف ذكره للأكماكن بدلالات كثيرة ومتتوعة، وفي

تلك الصفحات نحاول أن نبحث في ديوان (تدور بي دوائري) عن الدلالات وراء ذكر الأماكن في قصائده. اللدلات النفسيت للمكان:

إن خلاصـة الدلالات النفسية تتتهي إلى دلالتين اثتتين، همـا: دلالتة

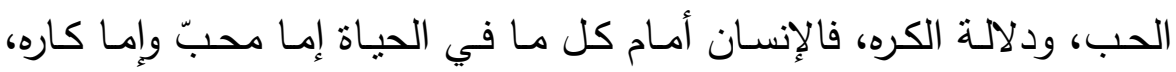
فالحب يشمل الإعجاب والأمل والحريـة والعزة والتفاؤل والفخر وغيرها، والكره يثمل اليأس والسخط والألم والقهر والإحباط والظلم ..إلخ. الد ائرة الأولى: دلالتّ الحبّ:

هناك العشرات من الأماكن التي ذكرها شاعرنا في ديوانها دهاته وكلها ذات دلالات متتوعة أهمها دلالة الحب، والحب عند شاعرنا هو الحب المطلق لكل الحياة بما فيها، من ذللك حب الوطن والحبيبة والأرض والفن والكون ...الخ، وقد ذكر الأماكن التي تدل على محبته تللك، ومن أهم تلاك الأماكن:

\section{(1) النيل والأرض والمقول والطين (الوطن)}

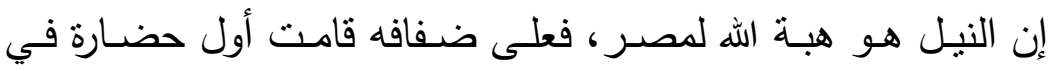

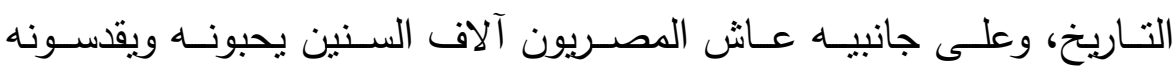
ويعتبرونه مصدر الحياة؛ لذا حرصوا أيما حرص على المحافظة عليه رافدًا يمدهم بالحياة وشريان تجري فيه روح المصريين، وقد عملوا على الحفاظ عليه من كل ما يهدده، وقد كُتب على جدران مقياس النيل بمعبد حورس في مدينة إدفو : (إذا انخفض منسوب النهر فلبهرع جنود الملك ولا يعودوا إلا بعد تحرير النيل ممـا يقيد جريانـه)، حتى أنه كان مـن المعروف عندهم أن ممـا يُسـأل الإنسان عنه في الحياة الآخرة: (هل لوثت ماء النيل؟)، وقد عمل المصريون 
حوليتّ كليت اللغت العربيت بإيتاي البارود (العدد الثالث والثلاثون)

على المحافظة على تدفق مياه النيل إلى أرض مصر وعدم السماح لأي عائق

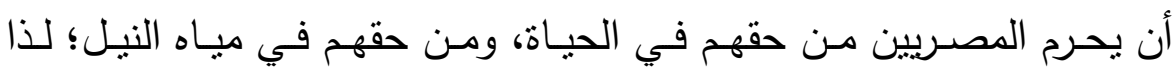
حرصوا في كل العصور على إقامـة علاقات طيبـة مـع دول المنبع باعتبار مصر دولـة المصب،، وفي بعض العصسور اضطر المصـريون إلى احتلال بعض دول المنبع التي هددت مصر بالعبث بالنيل، وما نراه الآن من بعض الت الدول التي تعيد التهديد نفسه، وما أظن مصر تسمح بذلك أبدًا.

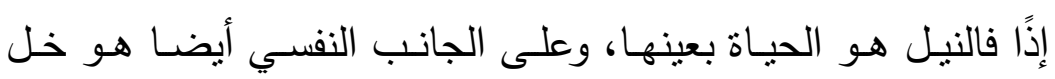
الثـراء وصديق الأدباء ورفيق العاثقين وملهم المبدعين ومنبع الحب عبر بهر

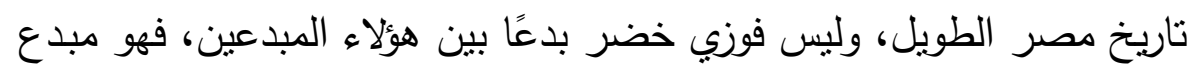
وفنان يحب النيل والأرض ويشتر بقيمة هذا النهر العظيم الخالد، فهو يزاوج مـا بين الأرض والنيل والحقول والطين ويجمع بينهما في أكثر من موضـع، فهو يعلم أن الحياة تدب في هذه الأرض حينما يأني النيل بخيره فيسقيها منه فتهنز وتربو، وتصبح الأرض ، ثم تخرج مـن خيرهـا ثـرات مختلف ألوانها وطعومها تسقى بماء واحد، ويعيش البشر ويفرح الحجر ابتهاجا بماء النيل .

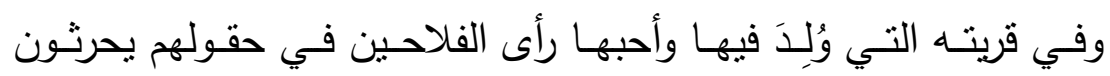

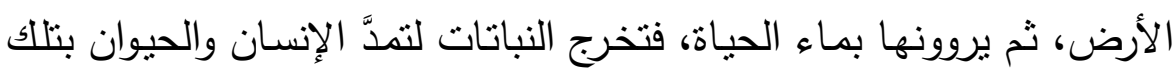
الحياة في ثوب جديد ليحيا الوطن. يقول مزاوجًا في حبه بين النيل والأرض في قريته (وطنه): أحكي عن النيل والأرض في قريتي/والعصافير والفجر والناس والأمنيات( ()

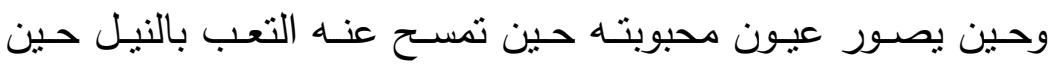
يفيض بخيره ويركض ماؤه في طريقه للأرض الظمآى، فيمسح أردانها ويحيي بـ بـن ما مات منها ... يقول: 
حوليت كليت اللغت العربيت بإيتاي البارود (العدد الثالث والثلاثون)

أنـادي على حافـة الهاويـه / عيونـك تمسـح عن جلدي الصـدأ / عيونـك نيـل

يفيض ..ويجتاح في ركضه الظمأ(1)

وفي قصيدته (مناجاة) يرى ما يمر بـه الوطن من مخاطر وصعوبات وفقر بسبب الجبناء الذين باعوه قد جعل أهله - وهو منهم - لا يجدون فيه ما يسد رمقهم، أو يقوض ، أو سكنًا يحميهم من الحر والقر، ويرى أن الجوع قد أنبت جيلًا لا يحمل في قلبه سوى الكره والبغضاء، ويتساءل كيف يحدث ذلك وكأننا لم يهبنا الله نيلاً يجري بالحب قبل الماء، وأرضا خضراء خصبة تتبت محبة أكثر ما تتبت عشبًا؟ فإذا فقدنا الحب فكأننا لا نيل لنا ولا أرض، بل صحراء جرداء ورمال وبيداء .. يقول:
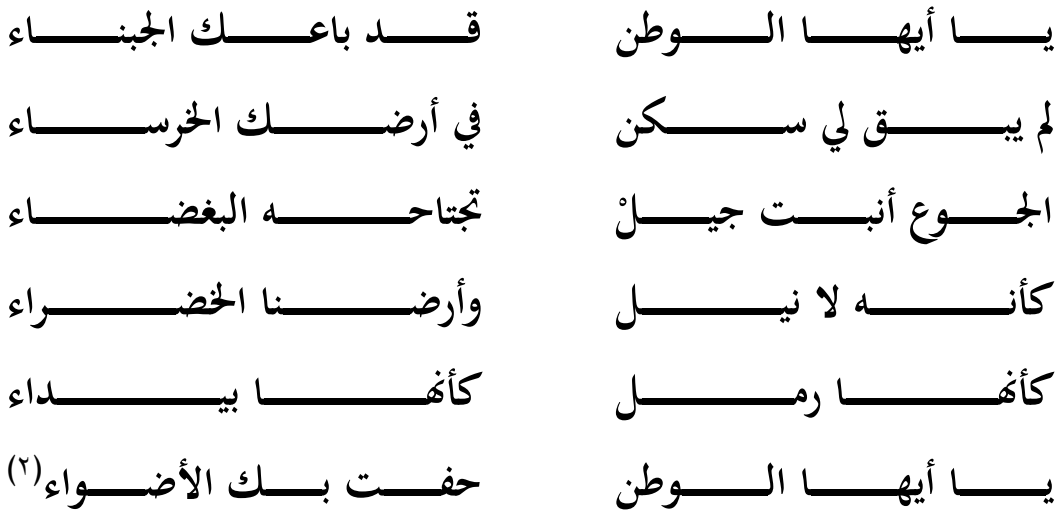

فيجمع بين (الوطن والسكن والأرض والنيل والرمل والبيداء) في إثـارة ودلالة نفسية على حبه للوطن وحزنه عليه حين باعه الجبناء، ولم يتركوا لله فيه سكنًا ولا مأوى. ويكرر المعنى ذاته في مقطوعـة بعنوان (بكاء)؛ حيث يبكي على

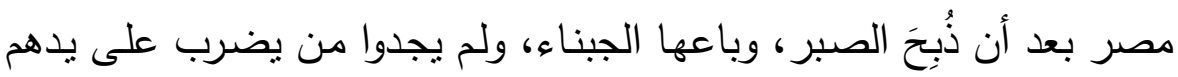
ويمنعه من ذلك، ولا يزال أهلها الطيبون يرتجون أملاً ربما لا يجيء أبدًا ...

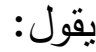




$$
\begin{aligned}
& \text { أبكي عليك الآن با مصر } \\
& \text { في كل يوم يُذبح الصبر } \\
& \text { باعولِ... لم يضرب على يدهم } \\
& \text { وعد ... ولا قهر .. ولا نصر } \\
& \text { في كل بوم نرتجي أملً } \\
& \text { بأتي لنا أدركه الكسر (1) }
\end{aligned}
$$

إنها الدلالة النفسية للحب تتجسد في النبل والأرض التي تعني الوطن

وتعني الحياة بعينها للمصربين عبر الزمان الطوبل، والتي لا يمكن أن تخيل هذه الحضـارة العظيمسة التي نبتت على أرض هذا البلد الطيب وبجوار نيله

العظيم، المكان هنا له نلك الدلالة التي لا تخفى على القارى الواعي. ولا زلنـا نلمس ـ في حديثه عن الأرض والحقول والنيـل ـ الدلالات النفسية لهذه الأماكن، ومدى تملكها من نفسه، ففي قصيدته المعنونة بـ (تلاتة وجوه لهذا الغصن) يقول: أفلق سطح الأرض /وأخرج أتلفتُ حولي / أنظر فوقي / أطلات في الأجواء صباح الخير/ أترك جذري يتمدد في الأرض على استحياء /أحلم أن أكبر الأري أصبح غصنًا / مجد النبـت /أن يصسبح غصسنًا / تأوي الطير إليهه / وتقوت الربح ثقبله (r)

فالمكـان هـو أرض بـلاده التـي يحبهـا وبعشـقها، ويتمنـى أن يصـبح غصنا من أغصانها يمدد فيها جذوره، ويغرس فيها نبته، ويعيش فيها ويكبر حتى يصبح غصنًا قويًَا وعضـوًا فاعلًا في المجتمع بنفع نفسه وغيره، فإلبه تأوي الطيور ، فتقف عليه لترناح وتستظل وتتام، وتداعبه الربح وتقبله بنسمات حلوة هانئة. 


$$
\text { وفي قصيدة بعنوان (بلادي) يقول: }
$$

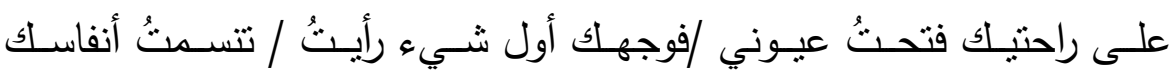

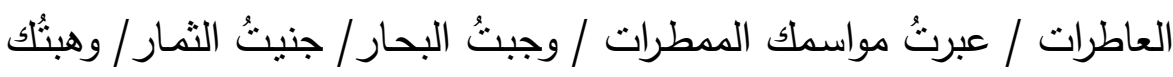

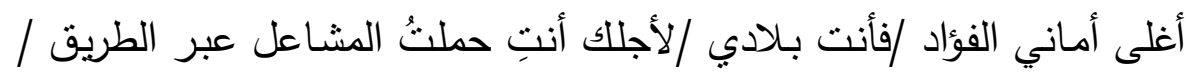

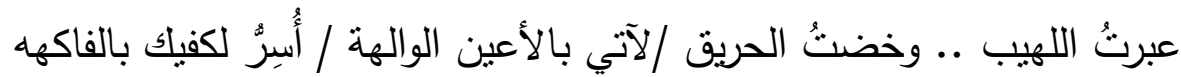

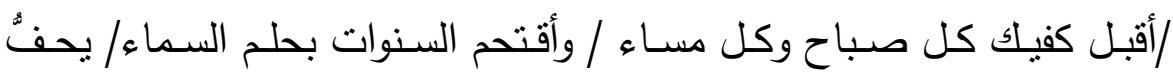
العطاء بروض الوداد / فأنت بلادي( (') الوكل إنها البلاد التي فتح عيونـه عليها، فرأى وجهها، وتتسم أنفاسها عبر

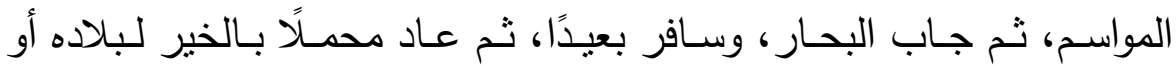
لمحبوبته التي تمثل الوطن والبلاد عنده، إنها الدلالة النفسية للمكان (الوطن) أو من في المكان، وهي(الحبيبـة) التي هي وطنه الذي يعود إليهه ويشتاق،

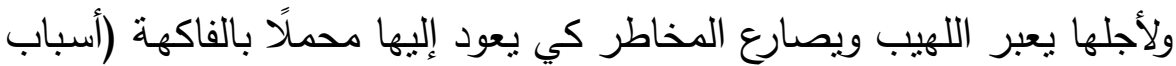
الحياة = المسال)؛ ليهديها إليها، ويجلس بين يديها، فيذهب التعب، وينتهي النصب، ويقى الوداد، وتأتي السكينة والأمس، فهي البلاد التي تحمل كل معاني الأمن والسلام والسكينة والراحة.

\section{(r)}

إن الإنسـان المسلم يتعلق قلبـه بـالحرمين الثـريفين، بخاصـة المسـد المد الحرام والكعبـة المشرفة؛ وذلك استجابة لدعوة أبي الأنبياء سيدنا إبراهيم في لإني

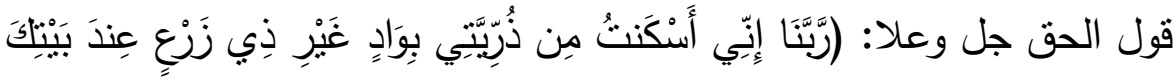

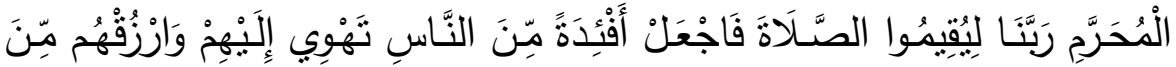

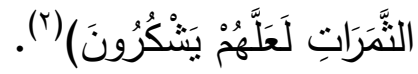

$$
\begin{aligned}
& \text { (1) السابق (1) } \\
& \text { r) سورة إبراهيم }
\end{aligned}
$$


حوليت كليت اللغت العربيت بإيتاي البارود (العدد الثالث والثلاثون)

فلهذه الأماكن روحانية خاصة تأخذ بالقلوب والعقول، ولا يجد المؤمن

راحة نفسية وأمانًا وسلامًا وطمأنينة في أي مكان آخر منل ما يجده فيها، وهو يحبها رغم أنفه وذلك استجابة لدعوة نبـي الله إبراهيم عليه السـلام، وشـاعرنا عاش دهرًا من عمره قريبًا من مكة المكرمة، بالتحديد في مدينة الطائف التي لا تبعد كثيـرا عن مكـة المكرمـة، وقد كـان كثير التـردد على الحرم للعمـرة والزيارة، ونجد في قصـائده دلالات متعددة على حبّه لهذا البلد الطيب، وفي

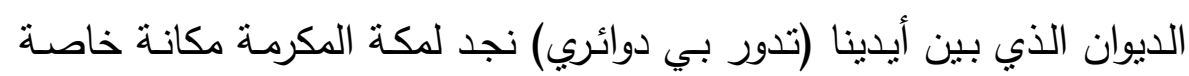

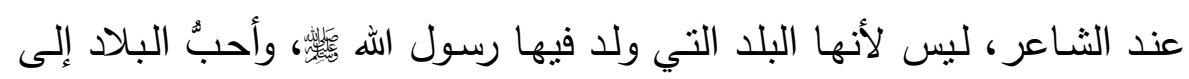
قلبه، ولكن لأن الثاعر أيضًا عمل لسنوات بالقرب منها (في مدينة الطائف)، وكان دائم التردد على مكة المكرمة، فيناجيها قائلا:

وما بين

الجبال الثمٍّ

ترتاحين صابحةً /أطراف النهار وفي الليالي/ يهتز قلبي حين تنظرك العيون/ بسيل منها: توبةٌ/ ندم؟/ أم يا ترى فرح اللقاء/ بساحة في الأرض ../ قد وصلت بإدراج

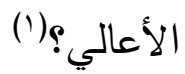
ويلعـب لفظظ "الأعـالي" ومشـتقاته دورًا محوريَّا أو مركزبَّا في تلـك القصيدة، وهـو لفظ ذو إيحـاءات متعددة في هذا المقام المكي، خاصــة أن

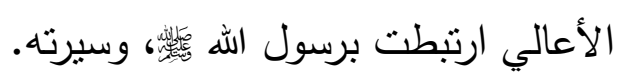
ونرى في قصيدة "مكة": أدراج المعالي، درج المعالي، درج العوالي، ألهوني، أعلى من عليات، أعلى هامة، عالي، رعوس الناس، أعلى الأعالي.

$$
\text { (1) (1) ديوان تدور بي دوائري } 9 \text { • } 1 \text { وما بعدها }
$$


ويقابل ذلك السجود الذي يعني الانحنـاء إلى أسفل، ووضـع الجبهة

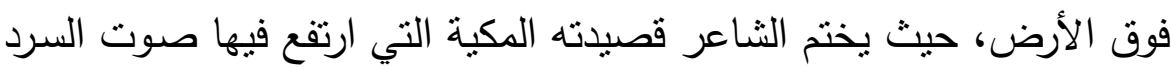
وغلبة الفعل الماضي، وكأنه يحكي لنا حكايته المكية، قائلًا: ورفعتُ عيني للسماء سرحتُ في أعلى الأعالي

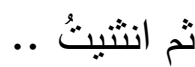
أطلتُ في الأرض السجودَ أطلت في الأرض السجود

وعلى الرغم من أن حركة السجود هي انجذاب نحو الأرض، إلا أنها تعني أيضا العلو والارتفاع الروحي، فأنت حينما تسجد لله سبحانه وتعالى، إنما تعلو وتحلق روحيا إلى مقام العرش والتواصل مع الله في أعلى عليين ('). (ب) دلانت الكره

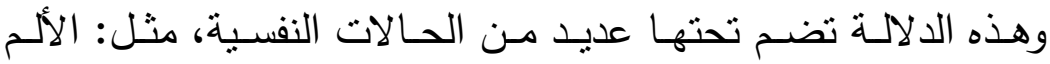
والإحباط والظلم والغربة، والغربة هي أهم المؤثرات النفسية في حياة شاعرنا، وأماكن الغربة المذكورة في شعره لها من الدلات الحزينة والمؤلمة مـا لا يعرفه إلا كل من ذاق طعم الغربة وعرف مرارتها، ومن ذللك:

\section{(1) أماكن الغربة هثل المدن الشارع الأرصفة المال والماعم والفنادق إلخ:}

لا يخفى على القارئ أن شاعرنا قضى ردحًا طويلًا من عمره مغتربا

عن وطنـه، ويرجـع ذلك إلى أسـباب طلب سـعة الـرزق والسـي وراء لقمـة العيش، ولكن بقيت هذه البلاد الغريبة والأمساكن التي يرتادها تمثل وجعًا دائمًا في قلبه، فـلا يستطيع أن يجعلها بديلًا عن الوطن والأهل، فهو يراها ثقيلة

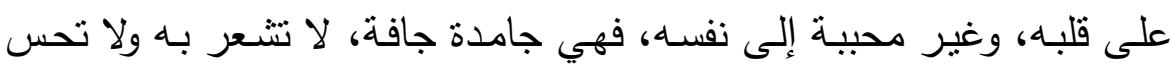
وحدته، ولا تشاركه أحزانه أو أفراحه: وعير

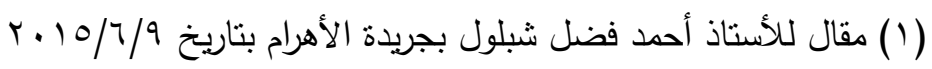




\section{حوليت كليت اللغت العربيت بإيتاي البارود (العدد الثالث والثلاثون)}

فالأرصفة في المدن المستبدة غبية لا قلب لها ولا شعور ، يجوع فيها الغرباء يقول في قصيدة (اقتسم الغرباء ثيابي)(') منها قوله : قال: فوق الرصيف غريب /فما سمعته القلوب / وجاء يراقبني اليوم/ جاء يدق

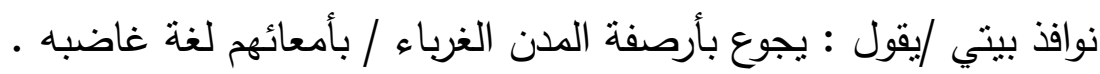
وفي غربته كان طعامه من المطاعم العامة التي لم يطمئن أبدًا إلى نظافتها، فهو يكرهها، ولكن لا مفر منها ... يقول: حشرات المطاعم تزحف في معدتي/ أتجشأ شاي المقاهي/ وأجنز نظرة عينيك/ لهون/ حين يسألني تائه عن مكان بعيد.

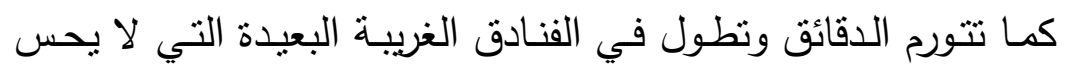

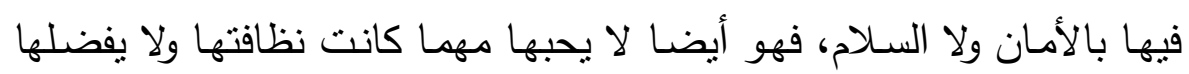
على بيته ووطنه:

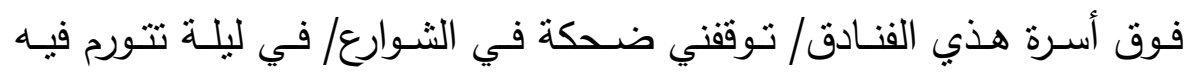

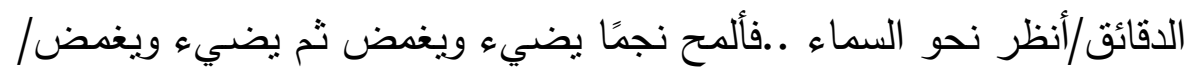
أغمض عيني ..أحلم ../ هل فجأة تجدين الذي غـاب/ يضـكك بين يديك

مساء؟(r)

أما الوطن فهو الراحة والسكن والأمن والأمان.

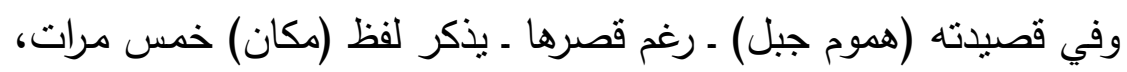
ويصور نفسه جبلًا يركض يبحث في وطنه عن مكان له، ولكنه لم يجده رغم اتساع الوطن وتتوعه، ورغم سفره وغربته إلا أنه يصر على أن يكون له مكان

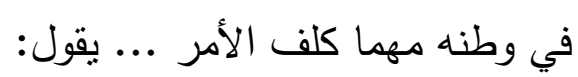
جبل يـركض / يبحث عن مأوى/ لو حجرًا كنتُ لأمكنتي أن أجد مكانًا بجوار جدار/ أو ألقي الجسد المجهد في أحد الأركان /أبحث عن مأوى /كانت

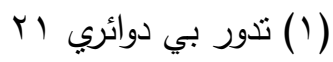




\section{حوليتّ كليت اللغت العربيت بإيتاي البارود (العدد الثالث والثلاثون)}

تنزاحم في الأرض بنايات /وديان ..رواب.. أنهار/لم ألق مكانًا يكفيني / هل

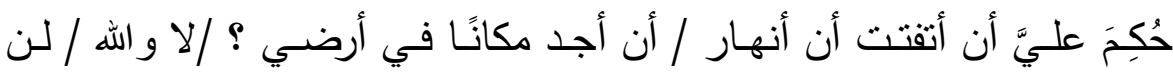
أصبح أحجارًا وصخورا / لن أصبح بعض فتات في الأرض / سأظل شموخا

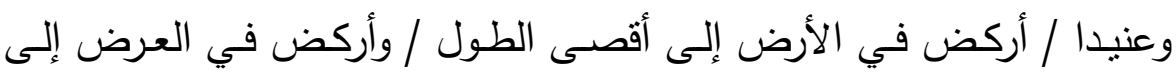

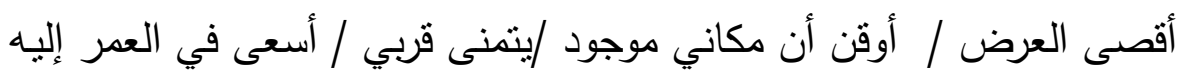

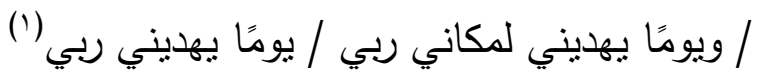
ومـن دلالات الحزن على بـلاده مصـر مـا كتبهـ في مقطوعـة بعنـوان

(بكاء) قال فيها:

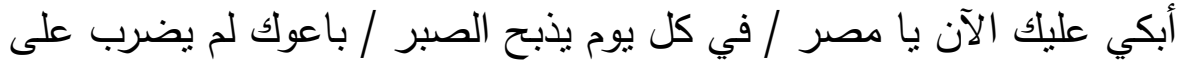

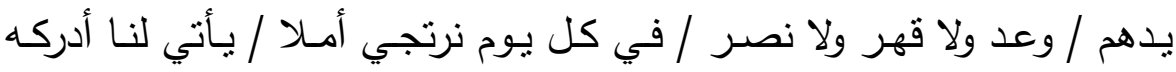

(r) (الكسر

"ومن الدلالات المهمة للغاية هي دلالة الأمل، والإصرار على تحقيق الحلم، وعدم اليأس والركون والثبات، إنه يرى الوطن - رغم حبه لـه ـ لا يعطيه حقه؛ لذا فقد هاجر واغترب كي يحقق ذاته وعيشّه الكريم، فيقول مخاطبًا وطنه في صورة محبوبته: إنه لن يرضى بالصبر، ولن يقتتع بالعيش؛ فهو الجواد المعاند

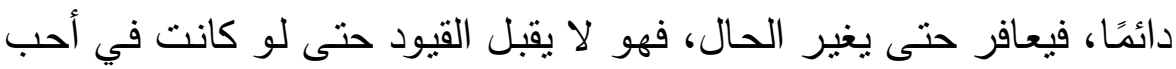
الأماكن ومع خير الناس، فخلق الجواد يرفض القيد حتى لو كان البراح. ساختُ بأرضِكِ ساقي

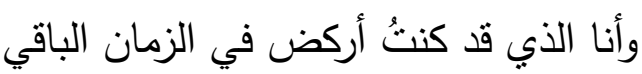
علّي أعانق صفحةَ الآفاق لكن أرضك. .كبلتني

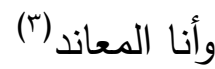$$
\text { (1) تدور بي دوائري سما (-عسا }
$$$$
\text { N r) السابق }
$$$$
\text { (r) النص ص r r (T- }
$$ 
حوليتة كليت اللغت العربيت بإيتاي البارود (العدد الثالث والثلاثون)

ومن جميل مقطوعاته حين يذكر الباب والنافذة دلالة أمل قادم يدخل منها

$$
\text { النور والنسمات ... يقول: }
$$

لا تيأس / إن أُغْلِق هذا الباب /لا زالت توجد نافذة / يدخل منها النور / وتأتي

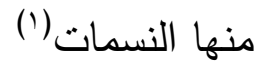

(ب) الدلالات الاجتماعيتش للمكان:

الثـاعر في كل زمان ومكان هو مرآة عصره ينعكس عليها أحداث العصر ومجرياته وصراعاته، والثـاعر هو جزء من المجتمع الذي يعيش فيه

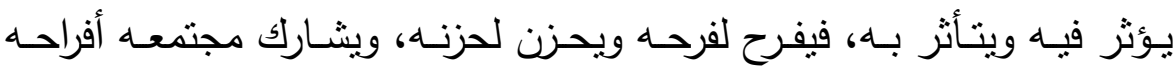
وأتراحه، فهو نتاج هذا المجتمع، ونبت غرسـه، وطرح نهره، وشـاعرنا تجسدت فيها كل تلك المعـاني في شعره عامـة، وفي هذا الديوان خاصـة، وقد حوى الديوان دلالات اجتماعية متعددة جسدها لنا عبر الأماكن التي ذكرها.

\section{(1) دلالة الفقر والهاجة:}

لقد عاش الثاعر ردحا من حياته يعاني كما يعاني منلاه من المنقفين والأدبـاء مـن شـظف العـيش وقصـر البـد، والثـاعر - كمـا عرفته - شـديد الاعتزاز بـالنفس، يحمل نفسـا تأبى الضيم، ولا ترضسى بـالظلم أبدًا، فلم يقبل يومًا هذا العيش الذي لا يليق بأمثاله، فهو يرى نفسه يستحق أن يعيش أفضل

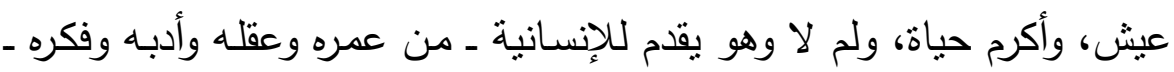

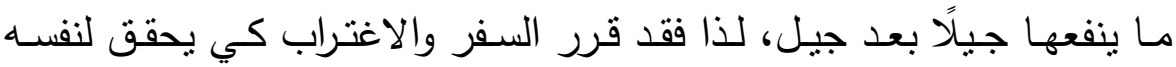
وأسرته الحياة التي تليق بهم، فنجد في شعره انعكاس هذه الحياة الفقيرة التي رفضـها وعمل على تغييرهـا، من ذللك تلك القصيدة الرائعـة بعنوان (محن)، يقول فيها:

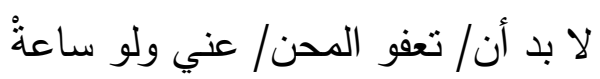

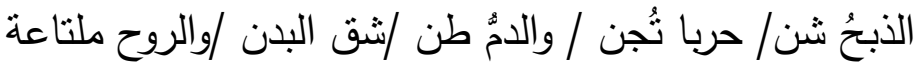


حوليتّ كليت اللغت العربيت بإيتاي البارود (العدد الثالث والثلاثون)

من لي بكن /فيه السكن /إن الوطن /قد باع مَن /قد ملَّ أوجاعه

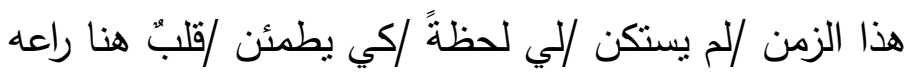

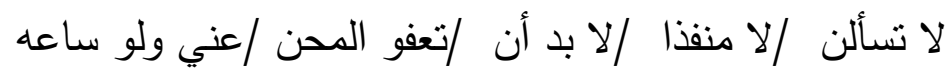

عني ولو ساعه (')

فالوطن هو محور القصيدة، وهو المكان الذي لم يجد فيه مبتغاه، بل هو

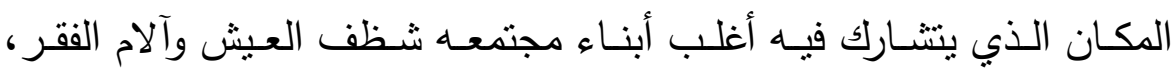
ونلاحظ أن المضمون هو الذي يفرض الثكل على صاحبه، فقصيدة عمودية شجنية منل "محن" كان لا بد أن تجيء في هذي هذا الثكل. ونلحظ في هذا الجزء من القصيدة أن قافية النون الساكنة قد أدت دورها في لي لئ إبراز صورة الأنين والثجن الذي يكابده الثـاعر في تجربته تلك، وأن تفعيلة

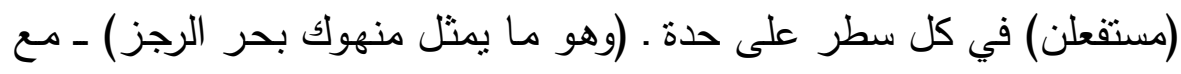

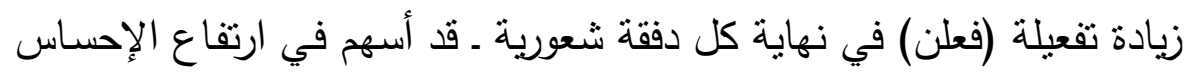
بمدى الإنهاك والفداحة الحياتية التي يحياها الثاعر. يقول الأستاذ أحمد فضل شبلول: (وقد شاهدتُ واستمعتُ إلى الثـاعر فوزي خضر يترنم بهذه القصيدة أو ينشدها ـ في أكثر من ندوة ومحفل شعري بطريقة مؤثرة كأنه يغنيها وهو يقطر ألمًا، فيطرب لها المستمعون ويتفاعلون

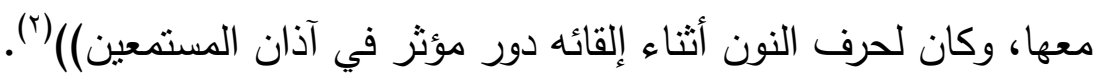

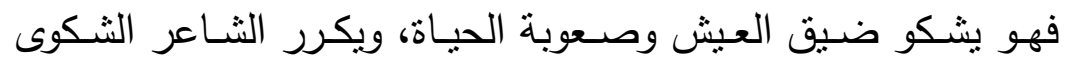
ويعرض ألمهه وحالـه الذي لا يرضـي بـه أحد، فقد طـال النزف ومـال السور وكثر الطعن، وكاد العمر يسيل من بين يديه في وطن لا يعطيه ما يسستحقه

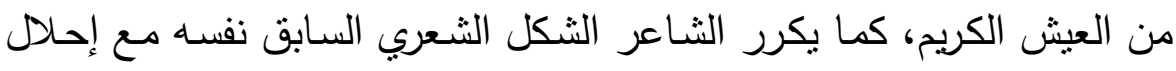
حرف اللام مكان النون في قصيدته "حلك" التي يقول فيها: 
حوليتة كليت اللغت العربيت بإيتاي البارود (العدد الثالث والثلاثون)

الحال حال/والنزف طال /والسور مال/حتى هلكث

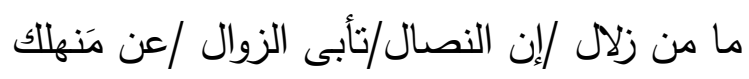

الطعن صال /والعمر سال/كيف النزال/والقيد للك.

ولعل الملحظ الثكلي هنا أن الثـاعر تخلى عن تفعيلة (فعلن) في نهاية كل دفقة أو كل مقطع في "حلك". ولكن لا بد أن أعترف أن تأثثر حرف هن النون كرويّ في "محن" كان أبلغ من حرف اللام كروي في "حلك."

\section{(ج) الدلالات السياسيت للمكان:}

إن شاعرنا يصب أكثر همّهـ على الجانب النفسي الإنساني والجانب البـان

الاجتماعي أكثر من الجانب السياسي، فإن كانت لله اهتماماته السياسية إلا أنها تأتي في المرتبة الثالثة بعد الجانبين النفسي والاجتماعي، وقد تتداخل كل

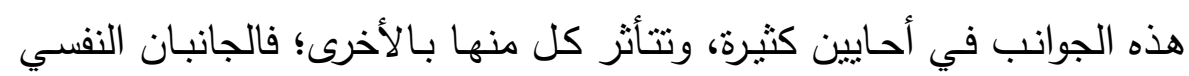
والاجتماعي ما هما إلا انعكاس للجانب السياسي، فالسياسة هي مدار الأمر ولئر كله.

والثـاعر يرهز بالمكان ذي الدلالـة السياسـة؛ كي يعبر عن شيء في صدره يفهمه القارئ من خلال فهمه لخصوصية المكان.

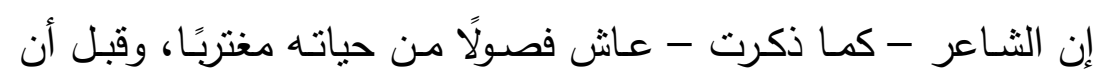
يغترب كان كثير السفر من الإسكندرية محل إقامته إلى القاهرة محل عمله غير الرسمي - وإبداعه في الإذاعة وغيرها، وكان وسيلته للسفر هي القطار ؛ لذا نجد للقطار والمحطة والرصيف مكانًا في شعره دلالة على كثرة السفر؛ للبحث عن أسباب الرزق. من ذلك قوله: أعرف الحزن قطارا تتلقاه المحطات طريدا / ثم تقصيه طريدا .......

يلتقت القب إليك/ ويركب الحزن /تلاقيه المحطات طريدا/ثم تقصيه طريدا(') 


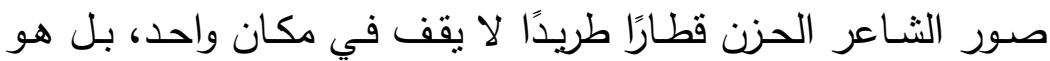

كثير التتقل لا يستقر به الحال في مكان طويلًا، وكأنه يصور نفسه من كثرة

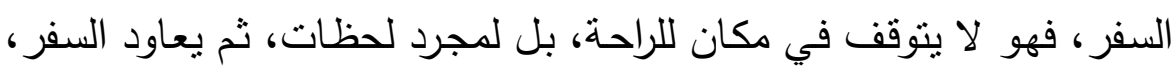

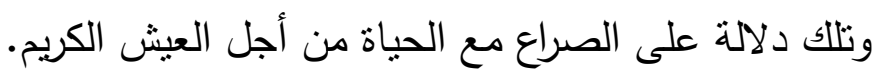

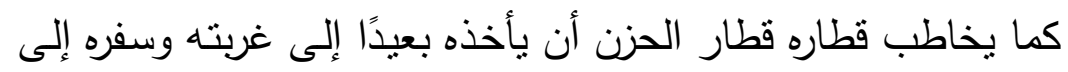
الجحيم - كما قال - عبر محطات اللهيب والحدائق المحترقة في الصدور؛ دلالة على عدم حبه للسفر ، وإنما اضطر إلى ذللك اضطرارًا ... يقول:

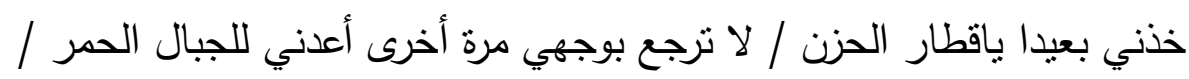

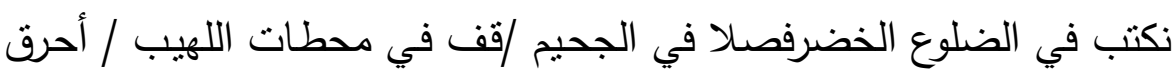

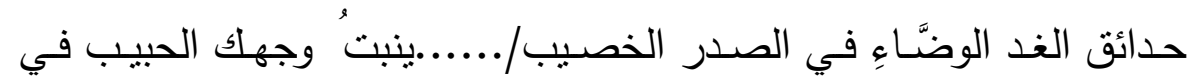
محطات القطار / غاضبا يصفعني / ويسكب اللهيب من سحائب النيران /في ساقية القلب أنادي صارخا أقذف من نافذة القطار أحلامي (') إن القطارات ـ بصوتها وصلصلتها ورجرجتها ـ حاضرة في أذنه وعقله دائمًا بسبب كثرة السفر واعتياد الغربة ... يقول: وصلنا إلى الحافة ...انتبهي تطن بأذني صلصلة العجلات جميعا ترجرجني القطارات جميعا ونزحف عبر دمائي (r) وله أيضًا واصفًا قسوة السفر وعذاباته وألم الاغتراب وكرباته، حين يجوع

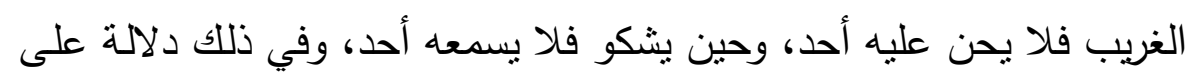
ضيق الحال الذي اضطره إلى الاغتراب والسفر ... يقول:

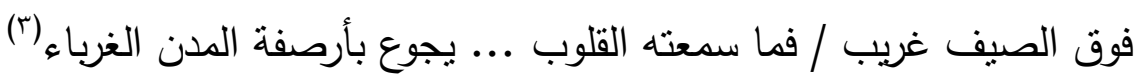


ول (القدس) في قلوب كل عربي مسلم مكانة عظيمة، وكذلك الحزن على

حالها عظيم أيضًا، وهي - بحالها - دلالة على حالنا العربي المقيت الذي لا لاني يخفى على أحد، ولكن هي أيضًا الهمّ الذي يجتمع العرب والمسلمون حوله، وهي القضية الكبرى لهم جميعًا، والأمل في عودتها لا يغيب أبدًا، فهناك نخلة

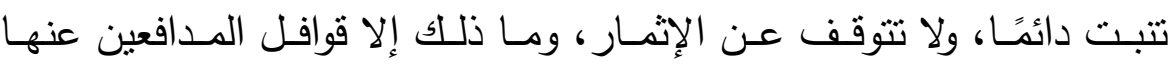
والمجاهدين لأجلها، والذين يولدون كل يوم يحملون الأمل الجديد في تحريرها وعودتها إلى أحضان أهلها.. يقول: في القدس تطلـع نخلـة /وبرغم سوط الريح يجلد ظهرهـا /وبرغم نـار الثـس

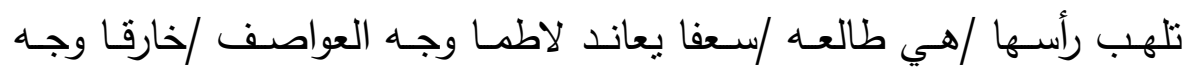

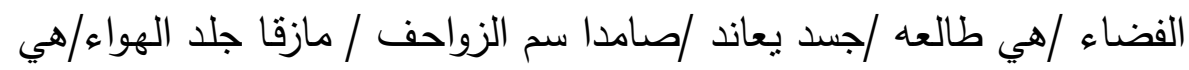

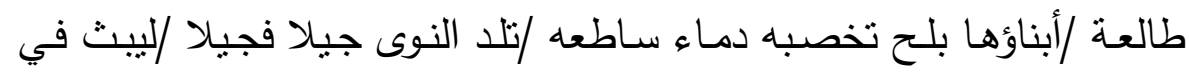
الأرض النخيلا /فيصيرسورا يمنع الأوغاد / يحمى القبة العصماء من عصف الغبار /يصير موجا من عناد / ويعيد أرضا ضائعه/ في القدس تطلع نخلة / الإوسئ

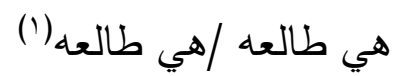
وكذلك لذكر (مكة المكرمـة) دلالـة سياسـة أخرى؛ فتلك الكعبـة التي

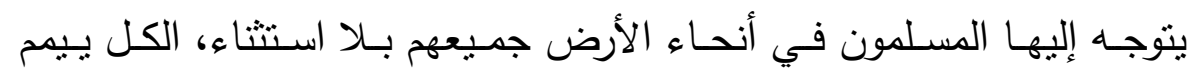
شطرها بوجهه مهما كان مذهبه، فهي رمز وحدة المسلمين واتفاق المؤمنين، فلم لا تكون لهم الآن وحدة سياسة تجمعهم كما كان من قبل؟ بهاب

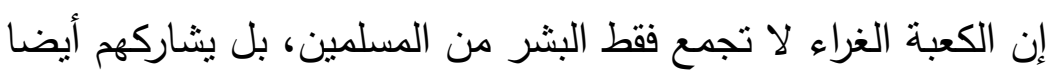
الطير والفراشات والأرواح التي لاقت ربها ... يقول:

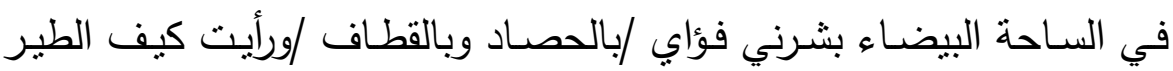
حول البيت طاف / وأتت فراشتات لطاف /فنزاحمت وتقاربت وتباعدت /أرواح 
من تلك التي جـاءت طيورا أو فراشـات/تطفو على رؤوس الناس داعيـة لهم

؟/في الساحة البيضاء يتسع الفضاء / في الساحة البيضاء يختصر الوجود(')

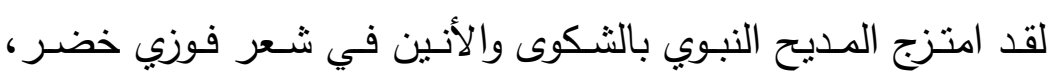
ولذكر المكان دلالة سياسية على حال المسلمين في الوقت الراهن، فالنثاعر بعد أن قدم ما يليق بالمقام النبوي في بداية القصيدة تتصاعد في قصيدته نبرة

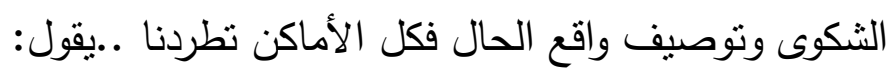

$$
\text { يليقإنا نعدو في طرقات رعناء }
$$$$
\text { يتركنا الموكب فوق رصيف الخوف }
$$$$
\text { إنا نقبض حبلا مقطوعا }
$$$$
\text { هل تذلي حبلك للجُبِّ }
$$

$$
\text { فنخرج }
$$

$$
\text { نحرس بيت المال .. المدن .. الأسماء؟(؟) }
$$

ويصـور الثـاعر المسـمين في العصـر الحسالي وكأنهم في جُبِّ لا لاهِ يعرفون الخروج منه، ويستغيث برسول الله لئل لأن ينقذهم من هذا الجب بإلقاء

حبله النبوي كي يخرجوا منه (r). إن الجب الذي عمد إلبه الثاعر يعد من أبلغ الدلالات الرمزية للمكان

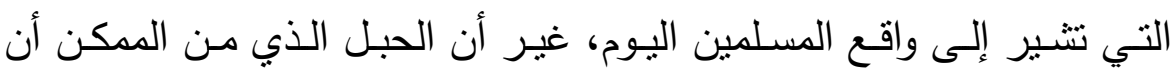
ينقذهم هو تمسكهم بقرآن الله والسنة النبوية المطهرة، مصداقًا لقول رسول الله 
حوليت كليت اللغت العربيت بإيتاي البارود (العدد الثالث والثلاثون)

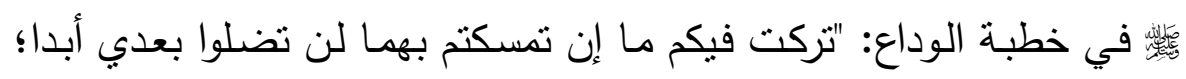

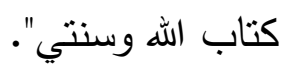

وتمتد الثكوى وتصسوير واقع حال المسلمين في القصبدة إلى أن

يقول الثناعر مصورًا ما هو كائن في بعض البلاد:

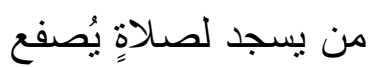

من يهتق باسمِكَ في أسماع مدينتخا

$$
\text { يعرف قول الآ }
$$

هكذا اسنطاع الثاعر توظيف المكان للتعبير عن دلالات متتوعة ما لاها

بين نفسية واجتماعية وسياسية، وقد كان لتك الدلالات الأثر النفسي الذي رمى دلى إليه الثاعر، ووظفه من أجلها. 


\section{الخخاتمه}

بعد تلك التطوافة والبحث عن المكان في ديوان (تدور بي دوائري) للشـاعر الدكتور / فوزي خضر نخلص إلى ما يلي: 1- استخدم الثاعر أغلب الأماكن الواقعية والخيالية في ديوانه. ץ- كان للمكان حضور قوي في ديوانه، رمى الشاعر إلى ذللك قصدًا. r- وظف الثاعر المكان حسب رؤيته التي يرمي إليها. ع - كان للأماكن المقدة دلالاتها المتميزة عن غيرها. ه-كان لاستدعاء المكان في الثُعر دلالات عديدة ومتتوعة، منها: النفسي، والاجتماعي، والسياسي. 


\section{الهراجع}

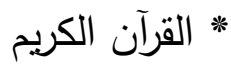

1- ابن منظور (أبو الفضل حمال الدين محمد بن مكرم بن علي بن منظور

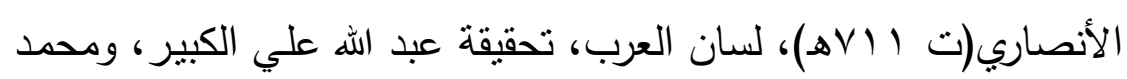

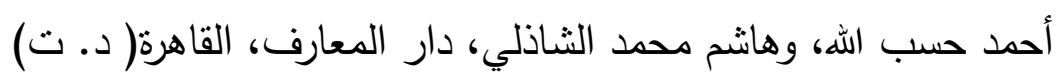

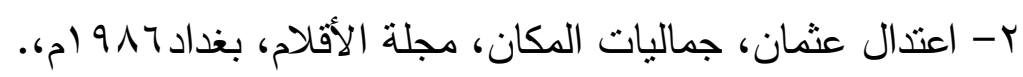

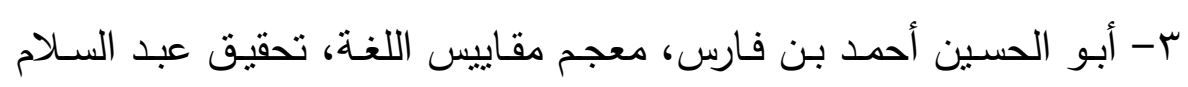

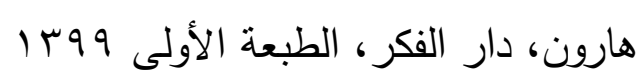

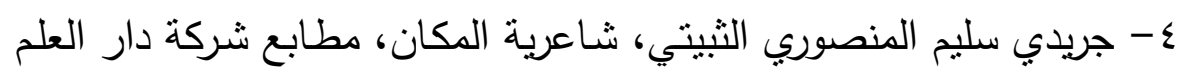

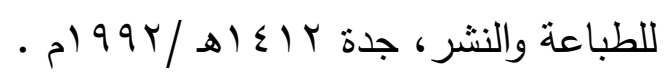

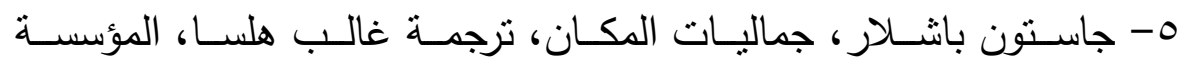

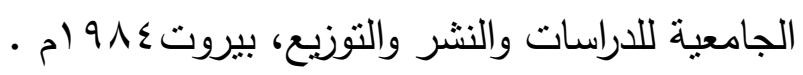

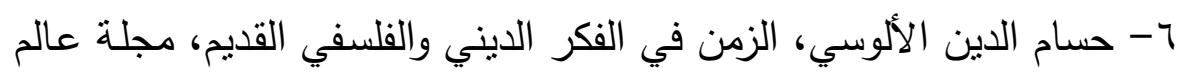

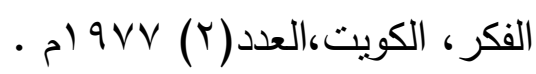

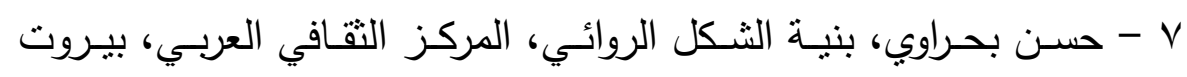
. 199 .

^- سامية أحمد، القصة القصيرة وقضية المكان، مجلة فصول، القاهرة، العدد

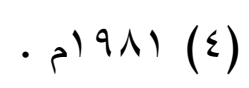

9- سيزا أحمد قاسم، بنـاء الروايـة، الهيئة الهصرية العامـة للكتاب، القاهرة

$$
\text { . }
$$

• (-شجاع مسلم العاني (دكتور)، البناء الفني في الرواية الفنية في العراق

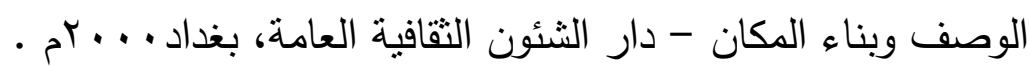

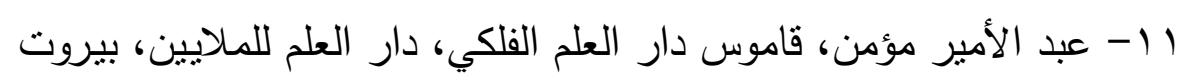
. 
حوليتة كليت اللغت العربيت بايتاي البارود (العدد الثالث والثلاثون)

rا - عبد الرحمن الخليـل بـن أحمد الفراهيدي (ت:00 ا اهـ)، كتاب العين، تحقيق: د. مهدي المخزومي و د. إبراهيم السامرائي، دار الثـئون والثقافة

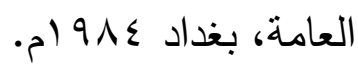

با -عبد الناصـر عيسوي حين انفصل الفارس عن جواده فوزي خضر في ائ

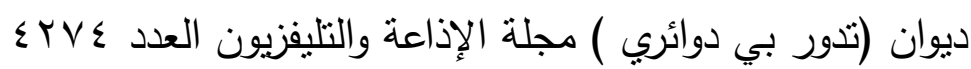
ع ا- علي عبد المعطي محمد (دكتور)، تيارات فلسفة معاصرة، دار المعرفة

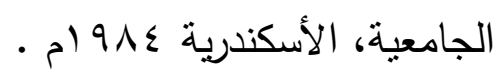

10 - فوزي خضـر ديوان تدور بـي دوائري الهيئة المصـرية العامـة للكتاب

$$
\text { r. } 10
$$

7 ا 1 - محمد عزام، فضاء النص الروائي، مقاربة بنيوية تكوينية في أدب نبيل

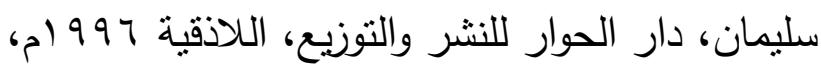
IV

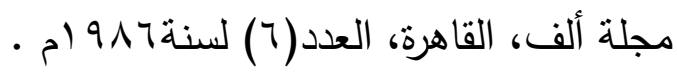

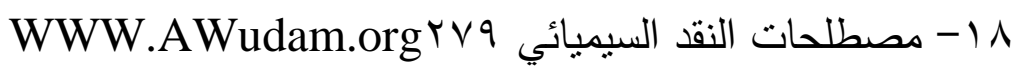

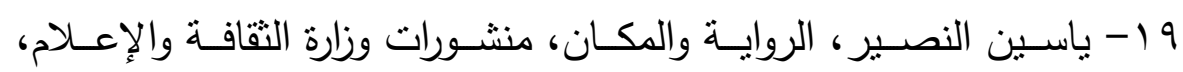
الجمهورية العراقية، سلسلة الموسوعة الصغيرة( IOV) • r - ياسين النصير ، إثكالية المكان في النص الأدبي، دار الثـئون الثقافية

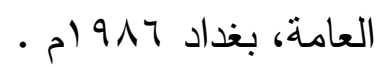

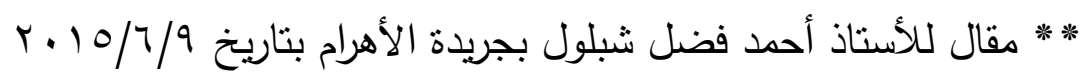


المنهربس

\begin{tabular}{|c|c|}
\hline رقهو الصفحت & الموضوع \\
\hline TヘY & والمقدمة و بها أسباب اختيار البحث للاراسة، والخطة \\
\hline TAYV & التمهيد : التعريف بالثاعر \\
\hline TA & المبحث الأول: المكان لغةًَ واصطلاحًا، ومفهوم \\
\hline$\neg \wedge \leq \leqslant$ & المبحث الثاني: المكان في شعر فوزي خضر \\
\hline$\neg \wedge \vee \varepsilon$ & أ- المبحث الثالث: دلالات المكان في شعر فوزي خضر \\
\hline $7 \wedge 91$ & الخاتمة التي تعرض أهم نتائج البحث. \\
\hline ҮА & ثبت بأهم المصادر والمراجع \\
\hline $7 \wedge 9 \leq$ & فهرس لموضوعات البحث \\
\hline
\end{tabular}

